OPEN ACCESS

Edited by:

Lehana Thabane,

McMaster University, Canada

Reviewed by:

Yoann Gaboreau,

Université Grenoble Alpes, France

Tze-Fan Chao,

Taipei Veterans Genera

Hospital, Taiwan

*Correspondence:

Gregory Y. H. Lip

gregory.lip@liverpool.ac.uk

tThese authors share senior authorship

Specialty section

This article was submitted to Family Medicine and Primary Care,

a section of the journal

Frontiers in Medicine

Received: 29 November 2019 Accepted: 05 February 2020

Published: 21 February 2020

Citation:

Ding WY, Harrison S, Gupta $D$ Lip GYH and Lane DA (2020) Stroke and Bleeding Risk Assessments in

Patients With Atrial Fibrillation:

Concepts and Controversies.

Front. Med. 7:54

doi: $10.3389 /$ fmed.2020.00054

\section{Stroke and Bleeding Risk Assessments in Patients With Atrial Fibrillation: Concepts and Controversies}

\author{
Wern Yew Ding ${ }^{1}$, Stephanie Harrison ${ }^{1}$, Dhiraj Gupta ${ }^{1}$, Gregory Y. H. Lip ${ }^{1,2 * t}$ and \\ Deirdre A. Lane ${ }^{1,2 \dagger}$ \\ 1 Liverpool Centre for Cardiovascular Science, Liverpool Heart and Chest Hospital, University of Liverpool, Liverpool, \\ United Kingdom, ${ }^{2}$ Aalborg Thrombosis Research Unit, Department of Clinical Medicine, Aalborg University, Aalborg, Denmark
}

Risk assessments are an important element in the management of patients with atrial fibrillation (AF). In this review, we aim to discuss the concepts and controversies surrounding the various risk factors for stroke and bleeding in AF. Indeed, there are a variety of clinical, electrical, biological, and genetic markers to guide stroke and bleeding risk assessments in AF. The more common factors have been used to formulate risk stratification scores. Some risk factors have shown promise, but others remain less well-defined. Our aim is to discuss concepts and controversies surrounding current evidence of risk factors for stroke and bleeding assessments in AF.

Keywords: stroke, bleeding, risk factors, risk assessment, atrial fibrillation

\section{INTRODUCTION}

Risk assessments are an important element in clinical practice. Therefore, it is crucial to understand the evidence supporting the individual risk factors to help guide management of patients with complex conditions such as atrial fibrillation (AF). Atrial fibrillation is the most common sustained cardiac arrhythmia. In 2010, the estimated global prevalence of AF was 33.5 million with approximately 5 million new cases identified (1). The condition is associated with a greater risk of stroke and heart failure, reduced quality of life, and a 2 -fold increased mortality (1-5). In addition, it poses a significant healthcare economic burden. Conservative estimates in the United Kingdom found that $\mathrm{AF}$ was associated with a direct annual cost of $\mathfrak{E} 459$ million, based on an estimated 0.5 million affected patients (6). However, as AF has detrimental effects on many other comorbidities, the total cost of AF is expected to be significantly higher. A study in the United States on AFrelated cost estimates this to be as high as $\$ 26$ billion per year (7). Perhaps most worryingly, the incidence and prevalence of AF is increasing worldwide $(8,9)$. Between 5.6 and 15.9 million people in the United States are projected to have AF by $2050(10,11)$ and 17.9 million people in Europe by 2060 (12).

Given the higher stroke risk associated with AF, an integrated approach in the management of patients with AF must include accurate stroke risk stratification. Patients who are not identified as "low risk" should then be offered anticoagulation therapy to reduce their risk of stroke. However, the use of anticoagulation carries an increased risk of bleeding. Most bleeding events are multifactorial in nature and some may have devastating clinical consequences. Therefore, it is important to consider and treat any modifiable bleeding risk factors prior to commencing anticoagulation. 
Overall, stroke and bleeding risk assessments in AF are complex with ever emerging evidence. Therefore, it can be challenging for clinicians to stay up to date with the most recent literature and appreciate the interplay of the various factors involved. This article is not an exhaustive systematic review of the vast literature on this topic. Our aim is to discuss concepts and controversies surrounding current evidence of risk factors for stroke and bleeding assessments in AF.

\section{STROKE RISK ASSESSMENT}

In general, $\mathrm{AF}$ is associated with a 5-fold increased risk of stroke (13). Furthermore, stroke outcomes are more severe in the presence of AF, as determined by clinical or radiological assessment $(14,15)$. Various factors based on clinical, electrical, biological, and genetic markers have been shown to predict stroke risk in AF (Table 1, Figure 1). Using a culmination of different risk factors, predominantly clinical, various authors have developed a total of at least 15 risk scores to assist stroke risk stratification in $\mathrm{AF}$ (16-19).

At present, the majority of clinical guidelines recommend the use of $\mathrm{CHA}_{2} \mathrm{DS}_{2}$-VASc score to aid decision on anticoagulation therapy (20-24). This tool was refined from the original 2006 Birmingham "National Institute for Health and Care Excellence" stroke risk schema with a specific focus on optimal identification of low-risk individuals and subsequently validated in several large AF cohorts $(18,25)$. In general, higher scores are associated with an increased annual risk of ischemic stroke. Males with a score of 0 and females with a score of 1 are considered at "low-risk" of stroke, with event rates $<1 \%$ per year. Current recommendations support consideration of anticoagulation therapy in all other patients where there is sufficient stroke risk to justify the hazards of anticoagulation.

Older studies have suggested that so-called "lone AF," contributes to an annual stroke risk of 1\% (26). However, more contemporary studies have found that stroke rate in such lowrisk patients is $<1 \%$ per year, as defined by age $<65$ years and the absence of any established stroke risk factors (27).

\section{Clinical Markers}

Atrial fibrillation is a multi-systemic disorder that often occurs alongside other comorbidities. Many of these co-morbidities are risk factors for incident $\mathrm{AF}$ and may also increase the risk of subsequent complications. Pooled analysis from five randomized controlled trials (RCTs) demonstrated that a history of stroke or transient ischemic attack (TIA), increasing age, hypertension, diabetes mellitus, and congestive heart failure were individual risk factors for stroke in AF (26). A more recent systematic review of seven studies which included over 12,000 patients found similar results, although there was inconclusive evidence to support congestive heart failure and coronary artery disease as risk factors (28). Prior stroke or TIA was the most powerful predictor of further stroke events, contributing to an annual risk of $>5 \%$. Increasing age (per decade), hypertension and diabetes mellitus were each associated with a 1.5-2-fold greater stroke risk. In a separate study, Olesen et al. demonstrated that the presence of heart failure, previous stroke, and vascular disease were independent predictors of stroke or thromboembolism among AF patients aged under 65 years (29). A Swedish cohort study found that peripheral artery disease, vascular disease, prior myocardial infarction, female sex, prior embolism, intracranial hemorrhage (ICH), hypertension, and diabetes mellitus were associated with additional thromboembolic events (25). The mechanism by which the conditions above influence stroke risk in AF is likely multifactorial and partly related to its influence on progression of the disease through atrial substrate remodeling. Furthermore, many of these conditions are pro-thrombotic by nature.

Among non-anticoagulated patients in the ATRIA study, females had a $60 \%$ higher risk of thromboembolism compared to males (30). Similar findings were shown in a cohort of anticoagulated patients where females had a 2-fold higher risk of ischemic stroke (31). However, a subsequent population-based cohort study of 147,622 patients with AF failed to reproduce these results (32). A study by Nielsen et al. demonstrated similar rates of thromboembolism for both sexes among AF patients deemed

TABLE 1 | Risk factors for stroke in AF.

\begin{tabular}{|c|c|c|}
\hline & Risk factor & Possible risk factor \\
\hline $\begin{array}{l}\text { Clinical } \\
\text { markers }\end{array}$ & $\begin{array}{l}\text { Prior stroke, TIA or TE } \\
\text { Vascular disease }^{+} \\
\text {Increasing age } \\
\text { Congestive heart failure } \\
\text { Hypertension } \\
\text { Diabetes mellitus } \\
\text { Female sex* }\end{array}$ & \\
\hline $\begin{array}{l}\text { Electrical } \\
\text { markers }\end{array}$ & $\begin{array}{l}\text { AF burden } \\
\text { Cardioversion to SR } \\
\text { AF type }\end{array}$ & AF morphology \\
\hline \multicolumn{3}{|c|}{ BIOLOGICAL MARKERS } \\
\hline $\begin{array}{l}\text { Blood } \\
\text { markers }\end{array}$ & $\begin{array}{l}\text { Troponins I and T } \\
\text { BNP and NT-proBNP } \\
\text { Reduced eGFR } \\
\text { D-dimer } \\
\text { Interleukin-6 }\end{array}$ & $\begin{array}{l}\text { von Willebrand factor } \\
\text { Mean platelet volume } \\
\text { MMP-2 } \\
\text { NOX2-derived peptide } \\
\text { Soluble CD40 ligand } \\
\text { Tumor necrosis factor- } \alpha \\
\text { tPA } \\
\beta \text {-thromboglobulin }\end{array}$ \\
\hline $\begin{array}{l}\text { Urine } \\
\text { markers }\end{array}$ & & $\begin{array}{l}\text { Albuminuria } \\
\text { Prostaglandin } \mathrm{F}_{2 \alpha} \\
\text { 11-dehydro-thromboxane } \mathrm{B} 2\end{array}$ \\
\hline $\begin{array}{l}\text { Imaging } \\
\text { markers }\end{array}$ & $\begin{array}{l}\text { LAA thrombi } \\
\text { LA spontaneous echo contrast } \\
\text { LAA flow velocity } \\
\text { LAA morphology } \\
\text { LV dysfunction } \\
\text { LA enlargement }\end{array}$ & $\begin{array}{l}\text { LA fibrosis } \\
\text { LAA dimensions } \\
\text { Complex aortic plaque }\end{array}$ \\
\hline $\begin{array}{l}\text { Genetic } \\
\text { marker }\end{array}$ & $\begin{array}{l}\text { Genetic variants on chromosome } \\
4 \text { q25 }\end{array}$ & FGB 455 G/A polymorphism \\
\hline
\end{tabular}

$A F$, atrial fibrillation; BNP, B-type natriuretic peptide; eGFR, estimated glomerular filtration rate; $L A$, left atrial; $L A A$, left atrial appendage; $L V$, left ventricle; $M M P-2$, matrix metalloproteinase-2; NOX2, reduced nicotinamide adenine dinucleotide phosphate oxidase 2; NT-proBNP, N-terminal pro-B-type natriuretic peptide; SR, sinus rhythm; TE, thromboembolism; TIA, transient ischemic attack; TPA, tissue plasminogen activator. ${ }^{*}$ Risk modifier.

+ Includes prior myocardial infarction, peripheral artery disease, or aortic plaque. 


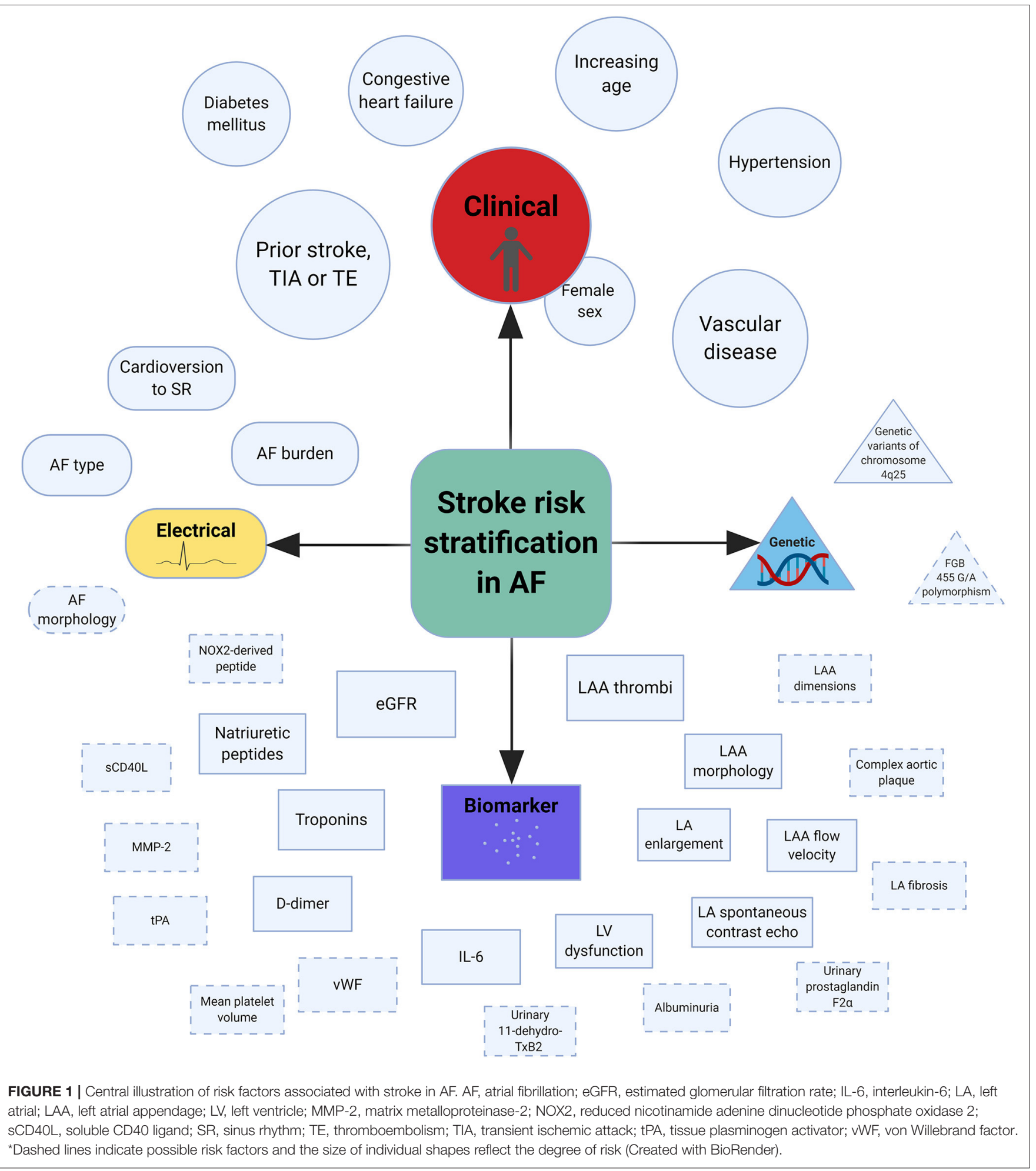

at lowest risk (33). Excess risk in females were only evident for those with two or more non-sex-related stroke risk factors. Therefore, although female sex should remain an important component for stroke risk assessment in AF, it should be considered in the context of other risk factors ("risk modifier").

\section{Electrical Markers}

Several electrical markers relating to AF have been described to predict stroke risk (Table 2). The impact of AF type (paroxysmal or sustained) on stroke risk remains controversial with earlier studies reporting a similar risk of stroke and systemic 
TABLE 2 | Electrical markers relating to AF and stroke risk.

\begin{tabular}{|c|c|c|c|c|c|c|c|c|}
\hline References & Design & Study population & $n$ & $\begin{array}{l}\% \text { male; mean } \\
\text { (SD) or median } \\
\text { (IQR) age, years }\end{array}$ & $\begin{array}{l}\text { Relevant outcome } \\
\text { measures }\end{array}$ & $\begin{array}{l}\text { Follow-up } \\
\text { duration }\end{array}$ & Electrical marker & Findings \\
\hline Chu et al. (34) & Retrospective cohort & $\begin{array}{l}\text { Undergoing pacemaker } \\
\text { implantation }\end{array}$ & 152 & $\begin{array}{c}56.4 \\
73.2(13.3)\end{array}$ & $\begin{array}{l}\text { Ischemic stroke, TIA or } \\
\text { SE }\end{array}$ & 67 months & AF burden & $\begin{array}{l}\text { Higher AF burden was associated with greater } \\
\text { risk of ischemic stroke, TIA, or SE }\end{array}$ \\
\hline Go et al. (35) & Retrospective cohort & $\begin{array}{l}\text { AF on 14-day ambulatory } \\
\text { ECG monitoring }\end{array}$ & 1,965 & $\begin{array}{c}55.2 ; \\
68.8(11.8)\end{array}$ & Ischemic stroke and SE & $\begin{array}{l}\text { NA } \\
\text { (retrospective) }\end{array}$ & AF burden & $\begin{array}{l}\text { Higher AF burden was associated with greater } \\
\text { risk of ischemic stroke or SE }\end{array}$ \\
\hline Link et al. (36) & Sub-analysis of RCT & $\begin{array}{l}\text { AF with at least } 2 \text { stroke risk } \\
\text { factors }\end{array}$ & 21,105 & $\begin{array}{c}61.9 \\
70.6(\mathrm{NA})\end{array}$ & Stroke or SE & 2.8 years & AF type & $\begin{array}{l}\text { Paroxysmal AF was associated with lower risk } \\
\text { of stroke or SE compared to persistent and } \\
\text { permanent AF }\end{array}$ \\
\hline Boriani et al. (37) & $\begin{array}{l}\text { Pooled analysis of } 5 \\
\text { prospective studies }\end{array}$ & Pacemaker or ICD in situ & 10,016 & $\begin{array}{c}69 ; \\
70(61-76)\end{array}$ & Ischemic stroke & 24 months & AF burden & $\begin{array}{l}\text { Higher AF burden was associated with greater } \\
\text { risk of ischemic stroke }\end{array}$ \\
\hline Healey et al. (38) & $\mathrm{RCT}$ & $\begin{array}{l}\text { Aged } \geq 65 \text { years, known } \\
\text { HTN and recent pacemaker } \\
\text { or ICD implanatation }\end{array}$ & 2,580 & $\begin{array}{c}58.4 \\
76.1(\mathrm{NA})\end{array}$ & Ischemic stroke or SE & 2.5 years & $\begin{array}{l}\text { AHRE } \\
\text { (>190 bpm for } \\
>6 \text { min) }\end{array}$ & $\begin{array}{l}\text { Presence of AHREs were associated with a } \\
5.6 \text {-fold greater risk of ischemic stroke or SE }\end{array}$ \\
\hline Friberg et al. (39) & Retrospective cohort & AF (or atrial flutter) & 1,981 & $\begin{array}{c}\mathrm{NA} ; \\
75.8(\mathrm{NA})\end{array}$ & Ischemic stroke & 3.6 years & AF type & No association with Ischemic stroke \\
\hline Yilmaz et al. (40) & Retrospective cohort & AF lasting longer than $24 \mathrm{~h}$ & 811 & $\begin{array}{l}45.9 \\
60(13)\end{array}$ & History of stroke or TIA & $\begin{array}{l}\text { NA } \\
\text { (retrospective) }\end{array}$ & Coarse or fine AF & $\begin{array}{l}\text { Coarse AF was associated with greater risk of } \\
\text { stroke or TIA }\end{array}$ \\
\hline $\begin{array}{l}\text { Hohnloser et al. } \\
\text { (41) }\end{array}$ & $\mathrm{RCT}$ & $\begin{array}{l}\text { AF with at least } 1 \text { stroke risk } \\
\text { factor }\end{array}$ & 6,706 & $\begin{array}{c}66 ; \\
70.2(\mathrm{NA})\end{array}$ & Stroke or SE & 1.3 years & AF type & No association with stroke or SE \\
\hline Capucci et al. (42) & Prospective cohort & $\begin{array}{l}\text { Indication for pacemaker } \\
\text { and history of symptomatic } \\
\text { atrial tachyarrhythmias }\end{array}$ & 725 & $\begin{array}{c}49.7 \\
71(11)\end{array}$ & $\begin{array}{l}\text { Ischemic stroke, TIA or } \\
\text { SE }\end{array}$ & 22 months & AF duration & $\begin{array}{l}\text { AF duration longer than } 24 \mathrm{~h} \text { was associated } \\
\text { with greater risk of ischemic stroke, TIA, or SE }\end{array}$ \\
\hline Glotzer et al. (43) & RCT & $\begin{array}{l}\text { SND undergoing } \\
\text { pacemaker implantation }\end{array}$ & 312 & $\begin{array}{c}45 \\
74(N A)\end{array}$ & $\begin{array}{l}\text { Death of non-fatal } \\
\text { stroke }\end{array}$ & 33.1 months & $\begin{array}{l}\text { AHRE ( }>220 \text { bpm } \\
\text { for } 10 \text { consecutive } \\
\text { beats) }\end{array}$ & $\begin{array}{l}\text { Presence of AHREs were associated with } \\
\text { greater risk of composite endpoint }\end{array}$ \\
\hline Hart et al. (44) & Prospective cohort & AF & 2,012 & $\begin{array}{c}71.5 \\
69.1(\mathrm{NA})\end{array}$ & Ischemic stroke & 2 years & AF type & No association with ischemic stroke \\
\hline
\end{tabular}

AF, atrial fibrillation; AHRE, atrial high rate episode; ECG, electrocardiogram; HTN, hypertension; ICD, implantable cardioverter defibrillator; IQR, interquartile range; NA, not applicable or available; RCT, randomized controlled trial; SD, standard deviation; SE, systemic embolism; SND, sinus node disease; TIA, transient ischemic attack. 
thromboembolism in paroxysmal AF compared to sustained or permanent $\operatorname{AF}(39,41,44)$. These results were supported by two independent systematic reviews which included a total of nine relevant studies $(28,45)$. However, a third systematic review of 12 studies which included just under 100,000 patients demonstrated that non-paroxysmal AF was associated with a hazard ratio of 1.38 [95\% confidence interval (CI), 1.171.57] for thromboembolism compared to paroxysmal AF, after multivariable adjustment (46). The finding was reinforced by results from the ENGAGE AF-TIMI 48 trial which showed fewer thromboembolic events among patients with paroxysmal AF compared to those with sustained AF (36). There was no difference in thromboembolic risk between patients with persistent and permanent AF in the study. Given the current evidence, it would appear that sustained AF is likely to be associated with a higher stroke risk overall. However, it remains unclear whether the increased risk is due to shared underlying mechanisms of the disease or if the burden of AF itself is directly implicated.

The method(s) by which AF is identified has evolved significantly over the past decade. While AF was previously detected predominantly using standard 12-lead electrocardiogram (ECG), the increased use of implantable devices has contributed to a rise in "device-detected AF." The rise of device-detected AF has also led to new terms such as "atrial high-rate episodes" (AHRE) and "subclinical atrial tachyarrhythmias"-both of which are sometimes used interchangeably with AF. These changes have sparked important questions such as "what duration of $\mathrm{AF}$ is required for diagnosis?", "what is the threshold of AF burden where it becomes clinically important?" and "what is the threshold of AF burden at which anticoagulation will provide a net benefit?" While many of these questions remain unanswered, there are some evidence to shed light on the matter. Several studies have investigated the threshold of AF burden associated with a negative clinical outcome. The MOST study found that patients with at least one AHRE (defined as an atrial rate $>220 \mathrm{bpm}$ ) lasting $\geq 5 \mathrm{~min}$ had a 2 -fold risk of stroke or mortality, and 6-fold risk of developing AF compared to patients without AHRE (43). The ASSERT study similarly found that subclinical atrial tachyarrhythmias (defined as an atrial rate $>190 \mathrm{bpm}$ ) lasting $>6$ min was associated with an increased risk of incident AF, and ischemic stroke or systemic embolism (38). In contrast, Capucci et al. performed a study using pre-specified AF durations in which the authors demonstrated that AF duration of $>5 \mathrm{~min}$ was not associated with thromboembolic events unlike episodes $>24 \mathrm{~h}$ which were independently associated with thromboembolic events (42). A potential explanation for the differences observed in this study may be related to the fact that a significant proportion of patients had short episodes of AF (about $80 \%$ ). Pooled analysis of five prospective studies that included 10,016 patients with implantable devices found that $\mathrm{AF}$ burden was an independent predictor of ischemic stroke (37). In this study, patients with $1 \mathrm{~h}$ of $\mathrm{AF}$ per day were found to be at highest risk. Among patients with paroxysmal AF, authors of the KP-RHYTHM study reported a 3 -fold increased risk of thromboembolism in those with the highest tertile of AF burden
( $\geq 11.4 \%$ ) compared to the lower two tertiles, after adjusting for either ATRIA or $\mathrm{CHA}_{2} \mathrm{DS}_{2}$-VASc score (35). A further study in patients with dual-chamber pacemakers also confirmed that patients with thromboembolism had higher AF burden (34). Overall, AF burden may reflect the proportion of time spent in mechanical dyssynchrony, thereby promoting thrombus formation. Though it is recognized to be an important predictor of stroke risk, the exact relationship remains to be defined and further research is warranted. Furthermore, determining the AF burden in patients without implantable cardiac devices can be challenging.

There are also important considerations when treating patients with a high burden of AF. Although a strategy to reduce this burden may be appropriate for some patients, attempts to restore sinus rhythm is not without risk. The FibStroke study revealed that electrical and pharmacological cardioversions were related to occurrences of ischemic stroke (47). As the majority of events occurred in patients who underwent electrical cardioversion, it could be postulated that the delivery of electrical energy may have dislodged pre-formed thrombi. However, many of the stroke events only occurred after a significant time delay (median of 2 days) following cardioversion. Therefore, there are likely to be other factors involved. Furthermore, there are even reports of acute thromboembolic complications following spontaneous cardioversion of $\operatorname{AF}(48,49)$. A potential cause for this may be linked to atrial stunning that occurs regardless of the means of cardioversion (50).

It was previously suggested that the morphology of $\mathrm{AF}$ as assessed on ECG may be useful for stroke risk assessment. In a study of 811 consecutive patients, Yilmaz et al. classified AF based on surface ECG as "coarse" or "fine" AF, and was able to demonstrate that patients with coarse AF had increased risk of stroke (40). The authors defined "coarse" AF as the presence of undulations moving $\geq 1 \mathrm{~mm}$ from the isoelectric baseline with different morphologies and "fine" $\mathrm{AF}$ as the presence of minimal or no undulation from the isoelectric baseline. At present, there is insufficient evidence to draw any firm conclusions. Nevertheless, if deemed reliable, classification of AF according to the different morphologies on ECG may provide a readily assessible tool to support clinical decisions.

Given the increased risk of stroke in AF, it would seem plausible that a temporal relationship might exists between these two conditions. If true, it may provide us a method of identifying patients at the point of highest stroke risk in order to instigate additional protective measures to avoid this complication. However, an initial study by ASSERT investigators revealed that only $8 \%$ of patients had subclinical AF detected within 30 days before their stroke or systemic embolism (51). Thus far, there is no strong evidence to support a temporal relationship between the episodes of AF and stroke events.

\section{Biological Markers ("Biomarkers")}

Many biomarkers involving blood, urine, and structural parameters have been studied in AF and been shown to improve the accuracy of stroke risk stratification. Despite this, their clinical applicability remains limited. Possible reasons include inter- and intra-patient and assay variability; diurnal variation 
of the results obtained; costs involved; strong influences of associated comorbidities and treatments in AF on these parameters; and lack of specificity. As such, these biomarkers are mainly reserved for research purposes.

\section{Blood-Based Biomarkers}

In general, blood-based biomarkers may be divided into those that relate to cardiac function (troponins and natriuretic peptides), hemostatic processes [D-dimer, von Willebrand factor (vWF), soluble E-selectin, and P-selectin], inflammation [interleukin-6 (IL-6) and C-reactive protein (CRP)], or "others" (renal function) (Table 3).

\section{Cardiac function}

Troponins and natriuretic peptides are among the most frequently used cardiac biomarkers. Their value in a variety of cardiovascular diseases such as myocardial infarction and heart failure have previously been established $(80,81)$. Further studies have also consistently demonstrated that levels of these biomarkers may be used to improve predictions of stroke risk in AF $(57,62,65-67,71)$. A RE-LY sub-study found that elevations in troponin I and N-terminal pro-B-type natriuretic peptide (NTproBNP) were common among AF patients (66). Both were independently related to an increased risk of stroke and there was a graded relationship such that patients with higher levels of these cardiac biomarkers were at greater risk compared to those with lower levels. The highest quartile of NT-proBNP was associated with 2.4-fold greater risk of stroke compared to the lowest quartile while the higher tertile of troponin I was associated with a 2.0-fold greater risk of stroke compared to the lowest tertile. There are several proposed mechanisms for the prognostic value of these cardiac biomarkers. In AF, unlike heart failure, B-type natriuretic peptides (BNPs) may originate from the atria (82). This is supported by the fact that restoration of sinus rhythm is associated with a rapid fall in the level of natriuretic peptides $(83,84)$. The elevated levels of natriuretic peptides may reflect the degree of atrial stretch (85). This in turn indicates atrial dysfunction which is linked to thrombus formation (86). Meanwhile, troponins are released as a following myocardial injury which may promote a pro-thrombotic state. Furthermore, elevated levels of troponin has been associated with impaired left atrial function, as assessed by cardiac magnetic resonance imaging (MRI) (87).

\section{Renal function}

Another important biomarker in stroke risk stratification is renal function $(17,61,63,73)$. Impaired renal function was demonstrated to be a strong predictor of stroke and systemic embolism in the ROCKET AF and ATRIA study cohorts, second only to prior stroke or TIA (17). A meta-analysis of 18 studies involving 538,479 patients with AF demonstrated that estimated glomerular filtration rate (eGFR) was an independent risk factor for stroke or systemic embolism, with worsening chronic kidney disease (CKD) being associated with a greater increased risk (88). Indeed $\mathrm{AF}$ patients with the most severe form of $\mathrm{CKD}$ requiring dialysis may have a dramatic increase of 9.8 -fold in stroke risk
(89). Chronic kidney disease promotes a pro-thrombotic state by its effects on the individual components of Virchow's triad (90). It has been found to be associated with stasis of the left atrium (LA) $(91,92)$, impaired endothelial function (93-97) and enhanced platelet activation $(98,99)$. Furthermore, CKD is linked to the release of procoagulant and inflammatory biomarkers (99-101).

It was previously suggested that the inclusion of CKD as a risk factor may improve stroke prediction models (17). However, additional studies have found that it did not improve the discriminative capabilities of the $\mathrm{CHADS}_{2}$ and $\mathrm{CHA}_{2} \mathrm{DS}_{2}$-VASc scores $(63,102,103)$. To summarize prior results, a metaanalysis of eight studies found that the inclusion of CKD resulted in a slight improvement for stroke prediction by the $\mathrm{CHADS}_{2}$ score but not with the $\mathrm{CHA}_{2} \mathrm{DS}_{2}$-VASc score (88). Therefore, there is currently insufficient evidence to justify the addition of $\mathrm{CKD}$ to the guideline-recommended $\mathrm{CHA}_{2} \mathrm{DS}_{2}$ VASc score. This is perhaps unsurprising given that $\mathrm{CKD}$ is associated with the individual component risk factors within the $\mathrm{CHA}_{2} \mathrm{DS}_{2}$-VASc score.

\section{Hemostasis}

Stroke risk in AF is strongly related to the disruption of hemostasis, leading to a pro-thrombotic state. However, the hemostatic processes are complex and involve many different pathways. Therefore, it is important to understand which of these are affected in AF. D-dimer is a small protein fragment that is released following fibrinolysis. A prospective study of 509 patients with $\mathrm{AF}$, found that those with a D-dimer level of $<150 \mathrm{ng} / \mathrm{ml}$ had significantly lower risk of thromboembolic events compared to those with D-dimer level of $\geq 150 \mathrm{ng} / \mathrm{ml}$, $0.7 \%$ per year compared to $3.8 \%$ per year (76). Similar findings were demonstrated in other studies $(72,78)$. In contrast, You et al. reported that D-dimer was not an independent risk factor for ischemic stroke in AF despite finding a positive correlation between $\mathrm{D}$-dimer levels and stroke risk scores $\left(\mathrm{CHADS}_{2}\right.$ and $\mathrm{CHA}_{2} \mathrm{DS}_{2}$-VASc) (55). However, this study was retrospective in nature and only included non-anticoagulated patients. Overall, it does appear that D-dimer may be helpful for stroke risk stratification in AF.

Given the role of platelets in hemostasis, it would seem likely that platelet count may be associated with stroke risk. However, in a study of 124 patients with AF on non-vitamin K oral anticoagulants (NOAC), Janion-Sadowska et al. found no association between thrombocytopenia (platelet count $<100 \times$ $10^{9} / \mathrm{L}$ ) and the risk of stroke or TIA over a 55-month follow-up period (53). In contrast, Park et al. recently reported retrospective registry data on 10,978 patients with $\mathrm{AF}$ where patients with a platelet count $<100 \times 10^{9} / \mathrm{L}$ had a significantly lower stroke risk compared to those with a normal platelet count (52). A major difference between the trials was in terms of the use of anticoagulation. About half of the patients (55.4\%) in the latter trial were not anticoagulated and among those who were, warfarin was the main agent of choice $(96.8 \%)$. There is limited evidence to base any firm conclusions at present although it could be that thrombocytopenia is protective against stroke in AF.

Von Willebrand factor is a glycoprotein integral to hemostasis. Raised levels of vWF has been associated with a pro-thrombotic 
TABLE 3 | Blood-based biomarkers for stroke risk in AF.

\begin{tabular}{|c|c|c|c|c|c|c|c|c|}
\hline References & Design & Study population & $n$ & $\begin{array}{l}\% \text { male; mean } \\
\text { (SD) or median } \\
\text { (IQR) age, years }\end{array}$ & $\begin{array}{l}\text { Relevant outcome } \\
\text { measures }\end{array}$ & $\begin{array}{l}\text { Follow-up } \\
\text { duration }\end{array}$ & Biomarker & Findings \\
\hline Park et al. (52) & $\begin{array}{l}\text { Prospective } \\
\text { registry }\end{array}$ & AF & 10,978 & $\begin{array}{c}63.6 \\
73.5(11.8)\end{array}$ & Stroke & 42.6 months & $\begin{array}{l}\text { Platelet count } \\
\left(<100 \times 10^{9} / \mathrm{L}\right)\end{array}$ & $\begin{array}{l}\text { Lower platelet counts were associated with } \\
\text { lower risk of stroke }\end{array}$ \\
\hline $\begin{array}{l}\text { Janion-Sadowska } \\
\text { et al. (53) }\end{array}$ & $\begin{array}{l}\text { Prospective } \\
\text { cohort }\end{array}$ & AF on NOAC & 124 & $\begin{array}{c}33.1 \\
70.3(\mathrm{NA})\end{array}$ & Stroke or TIA & 55 months & $\begin{array}{l}\text { Platelet count } \\
\left(<100 \times 10^{9} / L\right)\end{array}$ & No association with stroke or TIA \\
\hline $\begin{array}{l}\text { Rivera-Caravaca } \\
\text { et al. (54) }\end{array}$ & $\begin{array}{l}\text { Prospective } \\
\text { cohort }\end{array}$ & $\begin{array}{l}\text { AF on } \mathrm{OAC} \text {, } \\
\text { attending clinic }\end{array}$ & 1,226 & $\begin{array}{c}49.7 \\
76(70-81)\end{array}$ & Ischemic stroke & 6.5 years & $\begin{array}{l}\text { Soluble fibrin } \\
\text { monomer complex }\end{array}$ & No association with ischemic stroke \\
\hline You and Tang (55) & $\begin{array}{l}\text { Case- } \\
\text { controlled } \\
\text { study }\end{array}$ & $\begin{array}{l}\text { Non- } \\
\text { anticoagulated } \\
\text { AF }\end{array}$ & 323 & $\begin{array}{c}63.8 \\
75.2(\mathrm{NA})\end{array}$ & Ischemic stroke & $\begin{array}{l}\text { NA } \\
\text { (retrospective) }\end{array}$ & D-dimer & No association with ischemic stroke \\
\hline Ancedy et al. (56) & $\begin{array}{l}\text { Prospective } \\
\text { cohort }\end{array}$ & Hospitalized AF & 122 & $\begin{array}{l}46 ; \\
70(14)\end{array}$ & $\begin{array}{l}\text { Composite of all-cause } \\
\text { death and stroke; } \\
\text { stroke }\end{array}$ & 5 years & vWF & $\begin{array}{l}\text { Higher vWF levels were associated with greater } \\
\text { risk of composite endpoint } \\
\text { No association with stroke risk only }\end{array}$ \\
\hline Hayashi et al. (57) & $\begin{array}{l}\text { Prospective } \\
\text { registry }\end{array}$ & AF & 1,013 & $\begin{array}{c}71.6 ; \\
72.8(9.7)\end{array}$ & Stroke, TIA, or SE & 25 months & BNP & $\begin{array}{l}\text { High BNP levels were associated with a } \\
\text { 3.9-fold greater risk of stroke, TIA, or SE }\end{array}$ \\
\hline Choi et al. (58) & $\begin{array}{l}\text { Prospective } \\
\text { cohort }\end{array}$ & $\mathrm{AF}$ & 352 & $\begin{array}{c}57.4 \\
68.4(12.1)\end{array}$ & $\begin{array}{l}\text { Composite of ischemic } \\
\text { stroke and incidental } \\
\text { LA thrombus }\end{array}$ & 35.4 months & $\begin{array}{l}\text { Antithrombin III } \\
\text { MPV }\end{array}$ & $\begin{array}{l}\text { No association with composite endpoint } \\
\text { High MPV levels were associated with a } \\
\text { 6.4-fold greater risk of composite endpoint }\end{array}$ \\
\hline \multirow[t]{3}{*}{ Aulin et al. (59) } & $\begin{array}{l}\text { Sub-study of } \\
\text { RCT }\end{array}$ & $\begin{array}{l}\text { AF with at least } 1 \\
\text { stroke risk factor }\end{array}$ & 6,187 & $\begin{array}{c}63.7 \\
72(67-77)\end{array}$ & Stroke or SE & 2 years & IL-6 & $\begin{array}{l}\text { Higher IL-6 levels were associated with greater } \\
\text { risk of stroke or SE }\end{array}$ \\
\hline & & & & & & & CRP & No association with stroke or SE \\
\hline & & & & & & & Fibrinogen & No association with stroke or SE \\
\hline Pignatelli et al. (60) & $\begin{array}{l}\text { Prospective } \\
\text { cohort }\end{array}$ & AF & 950 & $\begin{array}{c}55.5 \\
73.3(8.8)\end{array}$ & $\begin{array}{l}\text { Composite of stroke, } \\
\text { TIA, MI, and coronary } \\
\text { revascularization }\end{array}$ & 25.7 months & $\begin{array}{l}\text { Serum } \\
\text { NOX2-derived } \\
\text { peptide }\end{array}$ & $\begin{array}{l}\text { Higher serum NOX2-derived peptide levels } \\
\text { were associated with greater risk of composite } \\
\text { endpoint }\end{array}$ \\
\hline Banerjee et al. (61) & $\begin{array}{l}\text { Prospective } \\
\text { cohort }\end{array}$ & AF & 5,912 & $\begin{array}{c}62.9 \\
70.9(N A)\end{array}$ & Ischemic stroke or TE & 2.5 years & eGFR (MDRD) & $\begin{array}{l}\text { Lower levels of renal function were associated } \\
\text { with greater risk of ischemic stroke or TE }\end{array}$ \\
\hline Roldan et al. (62) & $\begin{array}{l}\text { Prospective } \\
\text { cohort }\end{array}$ & $\begin{array}{l}\text { AF on } \mathrm{OAC} \text {, } \\
\text { attending clinic }\end{array}$ & 1,172 & $\begin{array}{c}49 ; \\
76(71-81)\end{array}$ & Stroke or TIA & 34 months & NT-proBNP & $\begin{array}{l}\text { High NT-proBNP levels were associated with a } \\
2.7 \text {-fold greater stroke or TIA risk }\end{array}$ \\
\hline $\begin{array}{l}\text { Apostolakis et al. } \\
\text { (63) }\end{array}$ & $\begin{array}{l}\text { Post-hoc } \\
\text { analysis of } \\
\text { RCT }\end{array}$ & AF & 4,576 & $\begin{array}{l}66.5 \\
70(9)\end{array}$ & Stroke or SE & 10.8 months & $\begin{array}{l}\text { CrCl, eGFR } \\
\text { (MDRD, CKD-EPI) }\end{array}$ & $\begin{array}{l}\text { Lower levels of renal function were associated } \\
\text { with greater risk of stroke or SE }\end{array}$ \\
\hline \multirow[t]{2}{*}{$\begin{array}{l}\text { Krishnamoorthy } \\
\text { et al. (64) }\end{array}$} & $\begin{array}{l}\text { Prospective } \\
\text { cohort }\end{array}$ & AF, attending clinic & 423 & $\begin{array}{c}55.6 \\
72.7(8.4)\end{array}$ & $\begin{array}{l}\text { Composite of stroke, } \\
\text { acute Ml, and all-cause } \\
\text { mortality; Ischemic }\end{array}$ & 19 months & vWF & $\begin{array}{l}\text { Higher vWF levels were associated with greater } \\
\text { risk of composite endpoint and Ischemic stroke }\end{array}$ \\
\hline & & & & & stroke & & Soluble E-selectin & $\begin{array}{l}\text { Higher soluble E-selectin levels were } \\
\text { associated with greater risk of composite } \\
\text { endpoint and Ischemic stroke }\end{array}$ \\
\hline Hijazi et al. (65) & $\begin{array}{l}\text { Sub-study of } \\
\text { RCT }\end{array}$ & $\begin{array}{l}\text { AF with at least } 1 \\
\mathrm{CHADS}_{2} \text { risk } \\
\text { factor }\end{array}$ & 14,892 & $\begin{array}{l}64.4 \\
\text { NA }\end{array}$ & Stroke or SE & 1.9 years & NT-proBNP & $\begin{array}{l}\text { Higher NT-proBNP levels were associated with } \\
\text { greater risk of stroke or SE }\end{array}$ \\
\hline
\end{tabular}


TABLE 3 | Continued

Design

Study population

$\%$ male; mean

Relevant outcome

Follow-up

(IQR) age, years

measures

duration

$+2$

\begin{tabular}{|c|c|c|c|c|c|c|c|}
\hline Piccini et al. (17) & $\begin{array}{l}\text { Sub-study of } \\
\text { RCT }\end{array}$ & $\begin{array}{l}\text { AF with at least } 1 \\
\text { stroke risk factor }\end{array}$ & 14,264 & $\begin{array}{c}60.7 \\
73 \text { (NA) }\end{array}$ & Stroke or SE & 1.9 years & $\begin{array}{l}\text { CrCl, eGFR } \\
\text { (MDRD) }\end{array}$ \\
\hline Hijazi et al. (66) & $\begin{array}{l}\text { Sub-study of } \\
\text { RCT }\end{array}$ & $\begin{array}{l}\text { AF with at least } 1 \\
\text { stroke risk factor }\end{array}$ & 6,189 & $\begin{array}{c}63.7 ; \\
72(67-77)\end{array}$ & Stroke & 2.2 years & NT-proBNP \\
\hline
\end{tabular}

Highest quartile of NT-proBNP was associated with 2.4-fold greater risk of stroke or SE

compared to lowest quartile

Lower levels of renal function were associated with greater risk of stroke or SE; every

10- $\mathrm{mL} / \mathrm{min}$ decrease in $\mathrm{CrCl}$ resulted in

1.12-fold increase in risk; every $5 \mathrm{~mL} / \mathrm{min} / 1.73$ $\mathrm{m}^{2}$ decrease in eGFR (MDRD) resulted in

1.09-fold increase in risk

Higher NT-proBNP levels were associated with greater stroke risk

Highest quartile of NT-proBNP was associated with 2.4-fold greater risk of stroke compared to lowest quartile

Troponin I Higher troponin I levels were associated with greater stroke risk

Highest quartile of troponin I was associated with 2.0-fold greater risk of stroke compared to lowest quartile

\section{Roldan et al. (67) Prospective AF on OAC,}

attending clinic

930

$51 ;$

Stroke or TIA

2 years

Troponin T

High troponin T levels were associated with a

2.4-fold greater stroke or TIA risk

Ehrlich et al. (68) Prospective AF

cohort

63;

Composite of stroke, $\mathrm{MI}, \mathrm{SE}$, and all-cause

28 months

\section{IL-6}

$70(11)$

death

hsCRP

SCD4OL

vWF

SVCAM-1

Roldan et al. (69) $\begin{array}{ll}\begin{array}{l}\text { Prospective } \\ \text { cohort }\end{array} & \begin{array}{l}\text { AF on OAC, } \\ \text { attending clini }\end{array}\end{array}$

Ha et al. (70) Prospective

AF

cohort

cohort

Sadanaga et al.

(72)

No association with stroke or TIA

No association with composite endpoint

No association with composite endpoint

Higher MMP-2 levels were associated with greater risk of composite endpoint

No association with composite endpoint

Higher SVCAM-1 levels were associated with greater risk of composite endpoint

High vWF levels were associated with a greater risk of composite endpoint

Higher MPV levels were associated with greater ischemic stroke risk

Highest tertile of MPV was associated with a

5.0-fold greater risk of ischemic stroke

compared to lowest quartile

High BNP levels were associated with a 5.3-fold greater risk of ischemic stroke, TIA, or

High D-dimer levels were associated with a 15.8-fold greater risk of ischemic stroke, TIA, or SE 
TABLE 3 | Continued

\begin{tabular}{|c|c|c|c|c|c|c|c|c|}
\hline References & Design & Study population & $n$ & $\begin{array}{l}\% \text { male; mean } \\
\text { (SD) or median } \\
\text { (IQR) age, years }\end{array}$ & $\begin{array}{l}\text { Relevant outcome } \\
\text { measures }\end{array}$ & $\begin{array}{l}\text { Follow-up } \\
\text { duration }\end{array}$ & Biomarker & Findings \\
\hline Go et al. (73) & $\begin{array}{l}\text { Sub-study of } \\
\text { prospective } \\
\text { cohort }\end{array}$ & AF & 10,908 & $\begin{array}{c}57.2 \\
71.6(\mathrm{NA})\end{array}$ & TE & 3 years & eGFR (MDRD) & $\begin{array}{l}\text { Lower levels of renal function were associated } \\
\text { with greater TE risk }\end{array}$ \\
\hline \multirow[t]{9}{*}{ Pinto et al. (74) } & \multirow{9}{*}{$\begin{array}{l}\text { Prospective } \\
\text { cohort }\end{array}$} & \multirow[t]{9}{*}{ Chronic AF } & \multirow[t]{9}{*}{373} & \multirow{9}{*}{$\begin{array}{c}63.5 \\
66.1(7.4)\end{array}$} & \multirow[t]{9}{*}{ Ischemic stroke } & \multirow[t]{9}{*}{3 years } & IL-1 $\beta$ & No association with ischemic stroke \\
\hline & & & & & & & TNF- $\alpha$ & $\begin{array}{l}\text { Higher TNF- } \alpha \text { levels were associated with } \\
\text { greater ischemic stroke risk }\end{array}$ \\
\hline & & & & & & & IL-6 & $\begin{array}{l}\text { Higher IL-6 levels were associated with greater } \\
\text { ischemic stroke risk }\end{array}$ \\
\hline & & & & & & & IL-10 & No association with ischemic stroke \\
\hline & & & & & & & E-selectin & No association with ischemic stroke \\
\hline & & & & & & & P-selectin & No association with ischemic stroke \\
\hline & & & & & & & ICAM-1 & No association with ischemic stroke \\
\hline & & & & & & & VCAM-1 & No association with ischemic stroke \\
\hline & & & & & & & vWF & $\begin{array}{l}\text { Higher vWF levels were associated with greater } \\
\text { ischemic stroke risk }\end{array}$ \\
\hline Ferro et al. (75) & $\begin{array}{l}\text { Prospective } \\
\text { cohort }\end{array}$ & AF & 231 & $\begin{array}{c}48 ; \\
72.4(10.3)\end{array}$ & $\begin{array}{l}\text { Composite of stroke } \\
\text { and } \mathrm{Ml}\end{array}$ & 27.8 months & sCD4OL & $\begin{array}{l}\text { High SCD4OL levels were associated with a } \\
4.6 \text {-fold greater risk of composite endpoint }\end{array}$ \\
\hline \multirow[t]{4}{*}{ Nozawa et al. (76) } & \multirow[t]{4}{*}{$\begin{array}{l}\text { Prospective } \\
\text { cohort }\end{array}$} & \multirow[t]{4}{*}{ AF } & \multirow[t]{4}{*}{509} & \multirow[t]{4}{*}{$\begin{array}{c}64.8 \\
66.6(10.3)\end{array}$} & \multirow{4}{*}{$\begin{array}{l}\text { Composite of clinically } \\
\text { evident stroke, TIA, and } \\
\text { SE }\end{array}$} & \multirow[t]{4}{*}{2 years } & D-dimer & $\begin{array}{l}\text { High D-dimer levels were associated with a } \\
\text { greater risk of composite endpoint }\end{array}$ \\
\hline & & & & & & & $\mathrm{F} 1+2$ & No association with composite endpoint \\
\hline & & & & & & & Platelet factor 4 & No association with composite endpoint \\
\hline & & & & & & & $\beta$-thromboglobulin & No association with composite endpoint \\
\hline \multirow[t]{2}{*}{ Conway et al. (77) } & \multirow[t]{2}{*}{$\begin{array}{l}\text { Prospective } \\
\text { cohort }\end{array}$} & \multirow[t]{2}{*}{$A F$, attending clinic } & \multirow[t]{2}{*}{77} & \multirow[t]{2}{*}{$\begin{array}{c}57 \\
68(62-75)\end{array}$} & \multirow[t]{2}{*}{ Stroke } & \multirow[t]{2}{*}{6.3 years } & IL-6 & $\begin{array}{l}\text { High IL-6 levels were associated with a 2.9-fold } \\
\text { greater stroke risk }\end{array}$ \\
\hline & & & & & & & CRP & No association with stroke \\
\hline \multirow[t]{5}{*}{ Vene et al. (78) } & \multirow[t]{5}{*}{$\begin{array}{l}\text { Prospective } \\
\text { cohort }\end{array}$} & \multirow{5}{*}{$\begin{array}{l}\text { AF referred to } \\
\text { clinic for initiation } \\
\text { of OAC }\end{array}$} & \multirow[t]{5}{*}{113} & \multirow[t]{5}{*}{$\begin{array}{c}60 ; \\
70.2(5.4)\end{array}$} & \multirow{5}{*}{$\begin{array}{l}\text { Composite of stroke, } \\
\text { MI, SE, peripheral } \\
\text { vascular occlusion, and } \\
\text { cardiovascular death }\end{array}$} & \multirow[t]{5}{*}{44.3 months } & D-dimer & $\begin{array}{l}\text { Higher D-dimer levels were associated with } \\
\text { greater risk of composite endpoint }\end{array}$ \\
\hline & & & & & & & tPA & $\begin{array}{l}\text { Higher tPA levels were associated with greater } \\
\text { risk of composite endpoint }\end{array}$ \\
\hline & & & & & & & $\mathrm{F} 1+2$ & No association with composite endpoint \\
\hline & & & & & & & TAT complexes & No association with composite endpoint \\
\hline & & & & & & & PAl-1 & No association with composite endpoint \\
\hline \multirow[t]{4}{*}{ Feinberg et al. (79) } & \multirow{4}{*}{$\begin{array}{l}\text { Sub-study of } \\
\text { prospective } \\
\text { cohort }\end{array}$} & \multirow{4}{*}{$\begin{array}{l}\text { AF with at least } 1 \\
\text { high-risk stroke } \\
\text { factor }\end{array}$} & 1,531 & $\mathrm{NA}$ & Ischemic stroke or SE & 2 years & $\mathrm{F} 1+2$ & No association with ischemic stroke or SE \\
\hline & & & & $70(\mathrm{NA})$ & & & $\beta$-thromboglobulin & No association with ischemic stroke or SE \\
\hline & & & & & & & Fibrinogen & No association with ischemic stroke or SE \\
\hline & & & & & & & $\begin{array}{l}\text { Factor V Leiden } \\
\text { mutation }\end{array}$ & No association with ischemic stroke or SE \\
\hline
\end{tabular}

AF, atrial fibrillation; BNP, B-type natriuretic peptide; CrCl, creatinine clearance; CRP, C-reactive protein; eGFR, estimated glomerular filtration rate; F1+2, prothrombin fragment F1+2; hsCRP, high-sensitivity C-reactive protein; ICAM-1, intercellular adhesion molecule-1; IL-10, interleukin-10; IL-1B, interleukin-1B; IL-6, interleukin-6; IQR, interquartile range; LA, left atrial; MDRD, Modification of Diet in Renal Disease Study; MI, myocardial infarction; MMP-2, matrix metalloproteinase-2; MPV, mean platelet volume; NA, not applicable or available; NOAC, non-vitamin K oral anticoagulants; NOX2, reduced nicotinamide adenine dinucleotide phosphate oxidase 2; NT-proBNP, N-terminal pro-B-type natriuretic peptide; OAC, oral anticoagulation; PAI-1, plasminogen activator inhibitor-1; RCT, randomized controlled trial; SCD4OL, soluble CD4O ligand; SD, standard deviation; SE, systemic embolism; sVCAM-1, soluble vascular cell adhesion molecule-1; TAT, thrombin-antithrombin; TE, thromboembolism; TIA, transient ischemic attack; TNF- $\alpha$, tumor necrosis factor-alpha; tPA, tissue plasminogen activator; vWF, von Willebrand factor. 
state in $\operatorname{AF}(56,64,69,74)$. However, a limitation in many of these studies was that the primary outcome measure included events such as heart failure and all-cause death. Therefore, it was difficult to draw strong conclusions from them. Among those that evaluated stroke only outcomes, two studies found that high levels of vWF was linked to a greater risk of stroke $(64,74)$. Despite demonstrating that higher levels of vWF were associated with a greater composite risk of all-cause death and stroke, Ancedy et al. found that the results were not significant when evaluated for stroke events only (56). Consequently, the role of $\mathrm{vWF}$ for stroke risk stratification in $\mathrm{AF}$ requires additional investigation.

\section{Inflammation}

There is ample evidence to support the importance of inflammation in AF. However, use of inflammatory biomarkers to predict stroke risk in this condition has been met with conflicting results. An early pilot study demonstrated that IL6 was an independent predictor of stroke risk in AF, but not CRP (77). Subsequently, Pinto et al. evaluated this by comparing plasma levels of interleukin-1 $\beta$, tumor necrosis factor-alpha, IL-6 and interleukin-10 (and E-selectin, P-selectin, intercellular adhesion molecule-1, vascular cell adhesion molecule-1 and vWF) in chronic AF patients with and without new-onset ischemic stroke over a period of 3 years (74). Following multivariable adjustment, only IL-6 and tumor necrosis factoralpha remained significant predictors of stroke risk. In a separate study, Aulin et al. postulated that levels of inflammatory markers (IL-6, CRP, and fibrinogen) may be related to the risk of thromboembolism in AF (59). After adjustment for clinical risk factors, only IL-6 was found to be significant. However, use of other biomarkers (troponin, NT-proBNP, and cystatin-C) attenuated the importance of IL-6 such that it was no longer predictive of stroke risk in AF. Other studies failed to demonstrate an association between thromboembolic risk in AF and levels of high-sensitivity CRP (68), IL6 (67), or fibrinogen (79). Given the current evidence, it appears that high levels of underlying inflammation as detected by IL-6 indicates a pro-thrombotic state in AF. There is no indication that CRP or fibrinogen are useful for this purpose.

In addition to the biomarkers mentioned above, there are others that have been evaluated in AF. Many have limited supporting evidence and require further studies to confirm their possible predictive capabilities. These include mean platelet volume, matrix metalloproteinase-2, reduced nicotinamide adenine dinucleotide phosphate oxidase 2-derived peptide, soluble CD40 ligand and tissue plasminogen activator $(58,60,68,70,75,78)$. There are also biomarkers that have not been thoroughly evaluated but thus far not been convincingly shown to be associated with stroke risk in AF. These include soluble fibrin monomer complex, antithrombin III, E-selectin, P-selectin, intercellular adhesion molecule-1, vascular cell adhesion molecule-1, prothrombin fragment $\mathrm{F} 1+2$, thrombinantithrombin complexes, plasminogen activator inhibitor-1, and $\beta$-thromboglobulin $(54,58,64,68,74,76,78,79)$.

\section{Urine Biomarkers}

Few urine biomarkers have been identified as possible predictors of stroke risk in AF. In the ATRIA study, presence of proteinuria was associated with a 1.5-fold increased risk of thromboembolism (73). In addition, a retrospective study demonstrated that higher levels of albuminuria were associated with greater risk of thromboembolism among patients with newly diagnosed AF (104). Possible mechanisms are: (1) albuminuria reflects early-stage CKD which has been shown to be related to stroke risk; (2) albuminuria causes an imbalance between naturally occurring pro-thrombotic and antithrombotic factors, such as that seen in nephrotic syndrome (105). Pignatelli et al. showed that higher urinary prostaglandin $\mathrm{F}_{2 \alpha}$ levels were associated with a greater composite risk of stroke, TIA, myocardial infarction and coronary revascularisation during a follow-up period of 26 months (60). Furthermore, urinary 11-dehydro-thromboxane $\mathrm{B} 2$ has also been found to be related to a composite risk of stroke, TIA, myocardial infarction, coronary revascularisation, and cardiovascular-related death among patients with AF (106). Overall, although urine biomarkers have not been comprehensively investigated in AF, they may represent an additional, simple, and non-invasive method to aid stroke risk stratification.

\section{Structural Biomarkers}

Atrial fibrillation causes significant structural changes including atrial remodeling that may be detected through a variety of imaging techniques. Some of these changes have been found to predict stroke risk in AF (Table 4), potentially by promoting abnormal blood stasis. Early studies in this area have relied predominantly on standard transthoracic echocardiography. Recently, advanced imaging modalities with increased accuracy such as trans-esophageal echocardiography, computed tomography, and MRI have become more widely available. This has allowed the discovery of new structural biomarkers such as LA fibrosis and left atrial appendage (LAA) morphology that may be used to refine stroke risk assessment in AF. The SPAF study evaluated the role of 14 echocardiographic parameters to predict incident ischemic stroke or systemic embolism in AF (117). The authors reported that the presence of left ventricular dysfunction and higher LA size were found to be important. Furthermore, these parameters were able to identify patients without clinical risk factors who were at higher risk of stroke. A prospective study of 2,713 patients with AF demonstrated that LA enlargement $(>45 \mathrm{~mm}$ ) was linked to a 1.7-fold increased risk of ischemic stroke or systemic embolism (108). Dakay et al. also found that more severe LA enlargement was associated with a greater risk of ischemic stroke despite anticoagulation (107). Interestingly, there appears to be an association between LA size and stroke risk even in the absence of AF. In the Framingham Heart study, non-AF patients with increased LA size were found to be at greater risk of stroke and mortality during the follow-up period of 8 years (118). The presence of LA enlargement may therefore be helpful to identify the subset of AF patients who remain at high-risk of stroke despite anticoagulation therapy. Furthermore, it can be assessed 
TABLE 4 | Structural biomarkers for stroke risk in AF.

\begin{tabular}{|c|c|c|c|c|c|c|c|c|}
\hline References & Design & Study population & $n$ & $\begin{array}{l}\% \text { male; mean } \\
(\mathrm{SD}) \text { age, years }\end{array}$ & $\begin{array}{l}\text { Relevant } \\
\text { outcome } \\
\text { measures }\end{array}$ & $\begin{array}{l}\text { Follow-up } \\
\text { duration }\end{array}$ & Biomarker & Findings \\
\hline $\begin{array}{l}\text { Dakay et al. } \\
\text { (107) }\end{array}$ & Prospective cohort & $\begin{array}{l}\text { AF hospitalized with } \\
\text { ischemic stroke }\end{array}$ & 225 & $\begin{array}{c}44.4 ; \\
79.5(10.5)\end{array}$ & $\begin{array}{l}\text { Anticoagulation } \\
\text { failure }\end{array}$ & NA & LAE & $\begin{array}{l}\text { More severe left atrial enlargement was associated with } \\
\text { greater risk of anticoagulation failure resulting in stroke }\end{array}$ \\
\hline $\begin{array}{l}\text { Hamatani } \\
\text { et al. (108) }\end{array}$ & $\begin{array}{l}\text { Prospective } \\
\text { registry }\end{array}$ & $\mathrm{AF}$ & 2,713 & $\begin{array}{c}60.2 \\
73.7(\mathrm{NA})\end{array}$ & $\begin{array}{l}\text { Ischemic stroke or } \\
\text { SE }\end{array}$ & 32.6 months & LAE & $\begin{array}{l}\text { LA diameter }>45 \mathrm{~mm} \text { was associated with a } 1.7 \text {-fold } \\
\text { greater risk of ischemic stroke or SE }\end{array}$ \\
\hline $\begin{array}{l}\text { Kong et al. } \\
\text { (109) }\end{array}$ & Prospective cohort & $\begin{array}{l}\text { Drug-refractory AF } \\
\text { undergoing catheter } \\
\text { ablation }\end{array}$ & 219 & $\begin{array}{c}65.3 ; \\
58.1 \text { (NA) }\end{array}$ & Stroke & $\begin{array}{l}\text { NA } \\
\text { (retrospective) }\end{array}$ & LAA morphology & $\begin{array}{l}\text { Non-chicken wing morphology was associated with } \\
5.8 \text {-fold greater stroke risk }\end{array}$ \\
\hline \multirow{4}{*}{$\begin{array}{l}\text { Khurram et al. } \\
\text { (110) }\end{array}$} & \multirow[t]{4}{*}{ Prospective cohort } & \multirow{4}{*}{$\begin{array}{l}\text { AF referred for catheter } \\
\text { ablation }\end{array}$} & \multirow[t]{4}{*}{678} & \multirow{4}{*}{$\begin{array}{c}74.8 \\
59.5(9.7)\end{array}$} & \multirow[t]{4}{*}{ Stroke or TIA } & \multirow{4}{*}{$\begin{array}{l}\text { NA } \\
\text { (retrospective) }\end{array}$} & LAA morphology & No association with stroke or TIA \\
\hline & & & & & & & LAA trabeculations & $\begin{array}{l}\text { Extensive LAA trabeculation was associated with a } \\
\text { greater stroke or TIA risk }\end{array}$ \\
\hline & & & & & & & LAA orifice diameter & $\begin{array}{l}\text { Smaller LAA orifice was associated with a greater stroke } \\
\text { or TIA risk }\end{array}$ \\
\hline & & & & & & & LAA length & $\begin{array}{l}\text { Shorter LAA length was associated with a greater stroke } \\
\text { or TIA risk }\end{array}$ \\
\hline $\begin{array}{l}\text { Kimura et al. } \\
\text { (111) }\end{array}$ & $\begin{array}{l}\text { Case-controlled } \\
\text { study }\end{array}$ & $\begin{array}{l}\text { Drug-refractory AF who } \\
\text { underwent catheter } \\
\text { ablation }\end{array}$ & 80 & $\begin{array}{c}82.5 \\
58.6(6.0)\end{array}$ & Stroke & $\begin{array}{l}\text { NA } \\
\text { (retrospective) }\end{array}$ & LAA morphology & $\begin{array}{l}\text { Cauliflower morphology was associated with a greater } \\
\text { stroke risk }\end{array}$ \\
\hline $\begin{array}{l}\text { Di Biase et al. } \\
\text { (112) }\end{array}$ & Prospective cohort & $\begin{array}{l}\text { Drug-refractory AF } \\
\text { undergoing catheter } \\
\text { ablation }\end{array}$ & 932 & $\begin{array}{c}79 \\
59(10)\end{array}$ & $\begin{array}{l}\text { Ischemic stroke or } \\
\text { TIA }\end{array}$ & $\begin{array}{l}\text { NA } \\
\text { (retrospective) }\end{array}$ & LAA morphology & $\begin{array}{l}\text { Chicken wing morphology was associated with lowest } \\
\text { risk of ischemic stroke or TIA; with chicken wing } \\
\text { morphology as reference, cactus, windsock and } \\
\text { cauliflower were associated with a } 4.1-, 4.5-\text {, and } \\
8.0 \text {-fold greater risks of ischemic stroke or TIA, } \\
\text { respectively }\end{array}$ \\
\hline \multirow{4}{*}{$\begin{array}{l}\text { Beinart et al. } \\
\text { (113) }\end{array}$} & \multirow{4}{*}{$\begin{array}{l}\text { Case-controlled } \\
\text { study }\end{array}$} & \multirow[t]{4}{*}{ Non-anticoagulated AF } & \multirow[t]{4}{*}{144} & \multirow{4}{*}{$\begin{array}{c}75 ; \\
54.5(9.9)\end{array}$} & \multirow[t]{4}{*}{ Stroke or TIA } & \multirow{4}{*}{$\begin{array}{l}\text { NA } \\
\text { (retrospective) }\end{array}$} & LAA volume & No association with stroke or TIA \\
\hline & & & & & & & LAA depth & No association with stroke or TIA \\
\hline & & & & & & & LAA neck dimensions & $\begin{array}{l}\text { High LAA neck dimension was associated with greater } \\
\text { stroke or TIA risk }\end{array}$ \\
\hline & & & & & & & LAA number of lobes & No association with stroke or TIA \\
\hline $\begin{array}{l}\text { Goldman } \\
\text { et al. (114) }\end{array}$ & $\begin{array}{l}\text { Sub-study of } \\
\text { prospective cohort }\end{array}$ & $\begin{array}{l}\text { AF with at least } 1 \\
\text { high-risk stroke factor* }\end{array}$ & 721 & $\begin{array}{l}76 \\
68(9)\end{array}$ & $\begin{array}{l}\text { Ischemic stroke or } \\
\text { SE }\end{array}$ & NA & $\begin{array}{l}\text { LAA peak antegrade } \\
\text { flow velocity }\end{array}$ & $\begin{array}{l}\text { LAA peak antegrade flow velocity }<20 \mathrm{~cm} / \mathrm{s} \text { was } \\
\text { associated with greater risk of Ischemic stroke or SE }\end{array}$ \\
\hline \multirow[t]{4}{*}{$\begin{array}{l}\text { Zabalgoitia } \\
\text { et al. (115) }\end{array}$} & \multirow[t]{4}{*}{$\begin{array}{l}\text { Sub-study of } \\
\text { prospective cohort }\end{array}$} & \multirow[t]{4}{*}{$\begin{array}{l}\text { AF with at least } 1 \\
\text { high-risk stroke factor* }\end{array}$} & \multirow[t]{4}{*}{786} & \multirow[t]{4}{*}{$\begin{array}{l}76 \\
69(9)\end{array}$} & \multirow[t]{4}{*}{$\begin{array}{l}\text { Ischemic stroke or } \\
\text { SE }\end{array}$} & \multirow[t]{4}{*}{ NA } & LAA thrombus & $\begin{array}{l}\text { Presence of LAA thrombus was associated with a } \\
2.5 \text {-fold greater risk of Ischemic stroke or SE }\end{array}$ \\
\hline & & & & & & & SEC & $\begin{array}{l}\text { Presence of SEC was associated with a 3.7-fold greater } \\
\text { risk of Ischemic stroke or SE }\end{array}$ \\
\hline & & & & & & & $\begin{array}{l}\text { LAA peak antegrade } \\
\text { flow velocity }\end{array}$ & $\begin{array}{l}\text { LAA peak antegrade flow velocity }<20 \mathrm{~cm} / \mathrm{s} \text { was } \\
\text { associated with a } 1.7 \text {-fold greater risk of Ischemic stroke } \\
\text { or SE }\end{array}$ \\
\hline & & & & & & & Complex aortic plaque & $\begin{array}{l}\text { Presence of complex aortic plaque was associated with } \\
\text { a 2.1-fold greater risk of Ischemic stroke or SE }\end{array}$ \\
\hline $\begin{array}{l}\text { Leung et al. } \\
\text { (116) }\end{array}$ & Prospective cohort & AF undergoing TOE & 272 & $\begin{array}{c}68 ; \\
68(11)\end{array}$ & Stroke or SE & 17.5 months & LA SEC & $\begin{array}{l}\text { Presence of LA SEC was associated with a 3.5-fold } \\
\text { greater risk of stroke or SE }\end{array}$ \\
\hline SPAF (117) & Sub-study of RCT & AF & 568 & $\begin{array}{c}70 \\
67(12)\end{array}$ & $\begin{array}{l}\text { Ischemic stroke or } \\
\text { SE }\end{array}$ & 1.3 years & $\begin{array}{l}14 \text { echocardiographic } \\
\text { parameters }\end{array}$ & $\begin{array}{l}\text { LV dysfunction and higher LA size were the associated } \\
\text { with greater risk of Ischemic stroke or SE }\end{array}$ \\
\hline
\end{tabular}

$A F$, atrial fibrillation; IQR, interquartile range; LA, left atrial; $L A A$, left atrial appendage; $L A E$, left atrial enlargement; $L V$, left ventricular; NA, not applicable or available; RCT, randomized controlled trial; SD, standard deviation; SE, systemic embolism; SEC, spontaneous echo contrast; TIA, transient ischemic attack; TOE, trans-esophageal echocardiography.

* Similar study cohort. 
on transthoracic echocardiography without the need for more complex imaging techniques.

The majority of cardioembolic strokes originate from the left atrium. In the LA, the most common site of thrombus formation is within the LAA. This is a small, complex, pouchlike sac attached to the anterior portion of the LA. Due to its complex anatomical structure and narrow inlet, the LAA is prone to abnormal blood stasis predisposing to thrombus formation. These thrombi may subsequently dislodge to cause a stroke. Therefore, it is perhaps unsurprising that certain LAA features have been shown to influence stroke risk. Unfortunately, these are rarely appreciated on standard transthoracic echocardiography which remains the most commonly used imaging method. The SPAF-III study demonstrated that among AF patients, ongoing arrhythmia during trans-esophageal assessment was associated with a lower LAA peak antegrade flow velocity $\left(A v_{p}\right)$ (114). Furthermore, the authors found that an LAA $\mathrm{Av}_{\mathrm{p}}<20 \mathrm{~cm} / \mathrm{s}$ was related to the presence of spontaneous echo contrast and LAA thrombus, and increased risk of cardioembolic events. Predictors of $\mathrm{Av}_{\mathrm{p}}<20 \mathrm{~cm} / \mathrm{s}$ were increasing age, higher systolic blood pressure, ischemic heart disease, and greater LA area. All of which are known risk factors for AF. In addition, the presence of spontaneous echo contrast and LAA thrombus have both been independently shown to be linked to greater stroke risk in AF $(115,116)$.

It is now recognized that the LAA is a complex structure with significant variation between patients. A study by Di Biase et al. found that among AF patients planned for catheter ablation, LAA morphologies could be categorized into four main groups based on their appearances on computed tomography or MRI (112). In order of reducing frequency, these were called "chicken wing" (48\%), "cactus" (30\%), "windsock" (19\%), and "cauliflower" (3\%). After multivariable adjustment, a chicken wing morphology was associated with the lowest risk of stroke. In comparison, there was a 4 -fold increased stroke risk with the cactus and windsock morphologies, and 8-fold increased stroke risk with the cauliflower morphology. Similar findings were also reported elsewhere $(109,111)$. However, a study by Khurram et al. failed to demonstrate any association between LAA morphology and risk of stroke or TIA (110). In addition, the authors found that there was significant inter-observer variability during determination of LAA morphology, indicating that this may be an unreliable method of assessment. Limitations of the studies assessing LAA morphology above lies in the fact that they were all retrospective in nature and included only a subset of AF patients, specifically those undergoing catheter ablation. Therefore, future prospective studies are needed to confirm whether LAA morphology may be used for stroke risk stratification in a general cohort of AF patients.

Other LAA parameters such as the number of lobes, neck dimension, overall dimension, volume, orifice diameter, and trabeculations have also been studied but again further evaluation is required $(110,113)$. Left atrial fibrosis may also represent an additional biomarker for stroke risk stratification. In a study of 178 patients with AF, LA fibrosis was assessed using late gadolinium enhancement MRI and correlated to transesophageal findings (119). The authors reported that high atrial fibrosis (>20\%) was linked to spontaneous echo contrast and LAA thrombus. Additionally, the presence of complex aortic plaques on trans-esophageal echocardiography defined based on features of mobility, ulceration, pedunculation, thickness $\geq 4 \mathrm{~mm}$, and location were found to be independently associated with a 2 -fold increased thromboembolic risk (115).

\section{Genetic Markers}

Improvements in genomic technologies have seen an increasing role for genetic testing in certain diseases. This may provide an additional element for risk stratification in AF. However, there have been few genetics studies in AF to date and they have largely focused on chromosome 4q25. It has been suggested that genetic variants on this chromosome may be related with ischemic stroke $(120,121)$. In a case-control study of 1,059 AF patients, after adjusting for potential confounders, FGB 455 G/A polymorphism was associated with increased cardioembolic stroke potentially through elevated fibrinogen levels (122). Factor $\mathrm{V}$ Leiden mutation has not been found to be predictive of thromboembolism in AF (79). Overall, more studies are needed to confirm these genetic findings. Even then, the use of genetic markers for stroke risk stratification in AF remains unrealistic at present.

\section{BLEEDING RISK ASSESSMENT}

A vital aspect of the management for AF includes stroke prevention. To this end, many patients require anticoagulation therapy. However, this approach is not without risk. A metaanalysis of eight RCTs found that the annual rates of major bleeding varied from 1.4 to $3.4 \%$ among patients with AF treated with warfarin (123). The risk of $\mathrm{ICH}$, the most serious form of bleeding, was estimated at $0.61 \%$ per year. Similar results were reported by Fang et al. in a cohort of 13,559 patients with AF treated with warfarin (124). Despite the relatively low rates of ICH, $76 \%$ of these patients had severe disability or died, and ICH was associated with at least a 20 -fold increased risk of 30 day mortality compared to other forms of bleeding. Given the detrimental consequences of anticoagulation-related bleeding in AF, especially with ICH, efforts should be directed at reducing this risk while maintaining adequate stroke prevention. The use of NOACs have been shown to be superior to warfarin in this regard. Two large meta-analysis have shown that NOACs, as a class of medications, have a better safety profile with less major bleeding and ICH when compared to warfarin $(125,126)$.

It is also important to consider the timing of anticoagulationrelated bleeding events. In this aspect, there appears to be an excess risk during the initial few months of treatment with vitamin $\mathrm{K}$ antagonist (VKA) (127). This may be due to poor anticoagulation control that eventually improves with time. However, there are likely to be additional factors involved as a similar effect was observed with dabigatran, where initial dose adjustments are rare (128). It is possible that the use of anticoagulation is simply unmasking high-risk individuals who were not identified using traditional assessment methods. Therefore, better risk profiling is necessary. Various factors based on clinical, biological, and genetic markers have been shown to 
predict the risk of anticoagulation-related bleeding in patients with AF (Table 5). Some of these factors may also influence the stroke risk.

There are several bleeding risk scores designed specifically for use in an AF cohort (Table 6). They have previously been summarized and include a combination of different clinical, biological and genetic markers (132). In general, each risk factor is assigned a score and the sum of these scores are used to estimate annual bleeding risk in an individual who is anticoagulated. It should be noted that there are differences in the way certain risk factors (e.g., age, renal dysfunction, and hypertension) have been defined between the various risk scores. Furthermore, many risk factors for bleeding contribute as well to stroke risk in AF. This highlights the complex relationship between thrombogenesis and bleeding, and represent the challenges faced by physicians when weighing up the risk and benefits of anticoagulation therapy (20).

\section{Clinical Markers}

An early study investigating the risk factors for bleeding among patients treated with warfarin found that age $\geq 65$ years, prior stroke, history of gastrointestinal bleeding, presence of serious comorbidity (such as recent myocardial infarction or renal impairment) and AF were important predictors (133). However, the study was limited by a small sample size and heterogenous cohort. Hughes et al. performed a systematic review of nine studies reporting on anticoagulation-related bleeding complications in AF to demonstrate that increasing age, uncontrolled hypertension, prior myocardial infarction or ischemic heart disease, prior stroke, anemia, history of bleeding, and concomitant use of other drugs (e.g., antiplatelets) were

TABLE 5 | Risk factors for anticoagulation-related bleeding.

\begin{tabular}{lll}
\hline & Risk factor & Possible risk factor \\
\hline Clinical & History of bleeding & Diabetes mellitus \\
markers & Antiplatelets or NSAID use & $\begin{array}{l}\text { Female sex } \\
\text { Excess alcohol }\end{array}$ \\
& Uncontrolled hypertension & Thyroid disease \\
& Increasing age & Prior Ml or known IHD \\
& Malignancy & \\
& Prior stroke & \\
& Vascular disease & \\
& Race/ethnicity (non-white) & \\
Biological & Choice of anticoagulant & Poor anticoagulation control \\
markers & (high INR or reduced TTR) & Interleukin-6 \\
& Liver dysfunction & Gon Willebrand factor \\
& Renal dysfunction & Troponins \\
& Anemia & \\
Genetic & Reduced platelet count & \\
marker & Cr function & \\
& CYP 2C9 polymorphism &
\end{tabular}

CYP, cytochrome P450; IHD, ischemic heart disease; INR, international normalized ratio; MI, myocardial infarction; NSAID, non-steroidal anti-inflammatory drug; TTR, time-intherapeutic range. independent risk factors for bleeding (134). Unlike previous studies $(135,136)$, diabetes mellitus and sex were not found to be important predictors. Conversely, age and concomitant use of antiplatelets have been consistently shown to significantly increase the risk of anticoagulation-related major bleeding (129, 135-137). Potential explanations for the increased risk of bleeding with age may relate to changes in metabolic clearance, higher prevalence of comorbidities, degenerative vascular changes, polypharmacy, and cognitive decline (138). Meanwhile, concomitant use of antiplatelets will interfere with additional hemostatic pathways that are necessary to prevent bleeding. Additional anticoagulation-related bleeding risk factors that have previously been described include excess alcohol intake and thyroid disease $(136,139)$.

\section{Falls}

Prior falls is perceived as a risk factor for anticoagulationrelated bleeding, especially in elderly patients. Gage et al. demonstrated a significantly increased risk of ICH associated with the use of warfarin in AF patients deemed at highrisk of falls (140). Based on this, such patients are often deprived of anticoagulant treatment for stroke prevention with

TABLE 6 | Bleeding risk scores in AF.

\begin{tabular}{|c|c|c|c|c|c|}
\hline Risk factors & $\begin{array}{c}\text { ABC- } \\
\text { bleeding } \\
\text { (129) }\end{array}$ & $\begin{array}{c}\text { ATRIA } \\
\text { bleeding } \\
(130)\end{array}$ & $\begin{array}{l}\text { HAS- } \\
\text { BLED } \\
(18)\end{array}$ & $\begin{array}{c}\text { HEMORR } \\
{ }_{2} \text { HAGES (131) }\end{array}$ & $\begin{array}{l}\text { ORBIT } \\
\text { (131) }\end{array}$ \\
\hline $\begin{array}{l}\text { Antiplatelets or } \\
\text { NSAID use }\end{array}$ & & & $x$ & & $x$ \\
\hline \multicolumn{6}{|l|}{ Diabetes mellitus } \\
\hline Excess alcohol & & & $x$ & $x$ & \\
\hline Excessive falls risk & & & & $x$ & \\
\hline Females & & & & & $x$ \\
\hline History of bleeding & $x$ & $x$ & $x$ & $x$ & $x$ \\
\hline Hypertension & & $x$ & $x$ & $x$ & \\
\hline Elderly patients & $x$ & $x$ & $x$ & $x$ & $x$ \\
\hline Malignancy & & & & $x$ & \\
\hline Previous stroke & & & $x$ & $x$ & \\
\hline $\begin{array}{l}\text { Abnormal liver } \\
\text { function }\end{array}$ & & & $x$ & $x$ & \\
\hline $\begin{array}{l}\text { Abnormal renal } \\
\text { function }\end{array}$ & & $x$ & $x$ & $x$ & $x$ \\
\hline Anemia & $x$ & $x$ & & $x$ & $x$ \\
\hline $\begin{array}{l}\text { Labile INR (TTR } \\
<60 \% \text { ) }\end{array}$ & & & $\mathrm{x}$ & & \\
\hline Raised GDF-15 & $x$ & & & & \\
\hline Raised hsTrop & $x$ & & & & \\
\hline $\begin{array}{l}\text { Reduced platelet } \\
\text { count or function }\end{array}$ & & & & $x$ & \\
\hline $\begin{array}{l}\text { CYP 2C9 } \\
\text { polymorphism }\end{array}$ & & & & $x$ & \\
\hline Total score & 45 & 10 & 9 & 12 & 7 \\
\hline
\end{tabular}

CYP, cytochrome P450; GDF-15, growth differentiation factor-15; hs Trop, high-sensitivity troponin; INR, international normalized ratio; NSAID, non-steroidal anti-inflammatory drug; TTR, time-in-therapeutic range. 
the assumption that it is harmful. However, it is important to recognize that within the same study, there was overall improvement in clinical outcomes among patients at highrisk of falls who received anticoagulation therapy, despite the increased risk of ICH. In a separate study involving 7,156 patients with AF, a history of falls was independently associated with a 3.3-fold increased risk of major bleeding (141). The authors remarked that assessment of "actual falls" may be more clinically useful than the "falls risk." This may provide an explanation for lack of association between falls and major bleeding events in a prospective study involving 515 patients on oral anticoagulation, where falls risk was used (142). Overall, the current evidence indicate that a history of falls may be an important risk factor for major bleeding but that this should not be the sole deterrent for anticoagulation in AF. In support of this, an earlier study by Man-Son-Hing et al. found that patients would need to fall an estimated 295 times per year for the risk of serious bleeding to outweigh the beneficial effects of warfarin (143).

\section{Malignancy}

Presence of a malignant disease has been associated with increased anticoagulation-related bleeding. A study by Gitter et al. found that patients with a malignant condition at the time of warfarin initiation had a 4 -fold greater risk of major hemorrhage during a 28-month follow-up period (144). Results from a secondary analysis of a prospective RCT demonstrated that the higher risk of bleeding was also observed with other anticoagulants such as heparin and danaparoid (145). Despite the overall increased risk of anticoagulation-related bleeding with malignant conditions, there exist variations in terms of safety and efficacy between the different options for anticoagulation. In general, low-molecular weight heparin has a similar safety profile to VKA and is superior for prevention of recurrent thromboembolism $(146,147)$. Non-vitamin K antagonist oral anticoagulants are a more convenient option to low-molecular weight heparin but may be associated with a higher risk of major bleeding with comparable effectiveness (147-149). Therefore, patients with malignant conditions who require anticoagulation therapy should be commenced on either low-molecular weight heparin or NOACs.

\section{Ethnicity}

A previous study of 28,628 patients from the GARFIELD-AF registry demonstrated that those with an Asian background had reduced risk of major bleeding compared to other ethnicities (150). However, subsequent studies have found that while the risk of ICH is higher among non-whites in general, it was up to 4 -fold higher in Asians compared to whites $(151,152)$. Furthermore, the complication was associated with worse outcomes in this group of patients (153). Given the current evidence, additional attention should be directed toward other modifiable bleeding risk factors in Asian patients commencing anticoagulation therapy. It may also be appropriate to consider NOACs in the first-instance as these have been found to be safer alternatives to VKA in this cohort (154).

\section{Weight}

Body weight is known to influence the distribution and clearance of anticoagulants (155). Therefore, there were concerns about the safety (and efficacy) of these medications in patients with extremes of body weight. However, studies on this topic have produced reassuring results. The risk of anticoagulation-related bleeding appears similar in underweight, and overweight or obese patients compared to those with normal body weight $(156,157)$. In fact, some studies have suggested that obesity may even be associated with reduced rates of bleeding (158-160). Furthermore, patients with obesity and AF who were treated with a NOAC had lower risk of thromboembolism, leading to the term "obesity paradox" (156-158).

\section{Biological Markers}

There are several biomarkers that may help predict anticoagulation-related bleeding. Some of these are linked to stroke risk and have already been described above (e.g., renal failure, IL-6, vWF). Perhaps one of the most important biomarkers associated with the use of VKA is the intensity of anticoagulation, measured as the international normalized ratio (INR). Higher INR levels have been found to increase the risk of anticoagulation-related bleeding, with relative risks (RR) for INR $\geq 4.5$ of 7.9 (95\% CI, 5.4-11.5) compared to INR $<4.5$ (127). It is estimated that every one unit increase in INR above 2.5 was associated with a 2 -fold increased risk of mortality (161). Therefore, every effort should be taken to maintain the INR of AF patients within pre-defined ranges, often between 2 and 3 (20). However, absolute INR levels alone can be misleading as a significant proportion of major bleeds occur despite the INR being in therapeutic range (162). More recently, INR variability has emerged as a more reliable assessment method for bleeding risk. A "labile INR" as determined using time-in-therapeutic range (TTR) is strongly linked to future bleeding events (163165). However, there are several limitations of TTR that are worth bearing in mind $(166,167)$. Firstly, it assumes a linear relationship between INR measurements which may not be true. Secondly, it does not inform on short-term risks associated with extreme deviations in INR. Lastly, it fails to account for individuals with "missed" monitoring periods who may represent a group at higher risk of bleeding due to reasons such as non-adherence.

Given the importance of the liver and kidneys in regulating pharmacokinetics of drugs and maintaining hemostasis, it is inevitable that fluctuations in the functions of these organs could negatively impact on anticoagulation-related bleeding. A prospective, observational study of $8,466 \mathrm{AF}$ patients treated with either VKA or NOACs suggests that both abnormal renal and liver functions were associated with increased risk of major bleeding (168). The study authors defined abnormal renal function as serum creatinine $>2.3 \mathrm{mg} / \mathrm{dL}(200 \mu \mathrm{mol} / \mathrm{L})$, prior renal transplantation or receiving chronic dialysis, and abnormal liver function as cirrhosis, elevated liver transaminases, or alkaline phosphatase $>3$ times above the upper limit of normal, or bilirubin $>2$ times above the upper limit of normal. Similar findings were reported in a separate large cohort study 
of 7,141 AF patients receiving rivaroxaban (169). Furthermore, Banerjee et al. reported that lower levels of eGFR were related to a greater risk of major bleeding over a study period of 2.5 years (61).

Anemia has also been linked to increased bleeding risk (133, $134,170)$. The underlying mechanism remains unclear but there is some evidence to suggest that platelet aggregation is impaired by a reduced red blood cell count (171). Furthermore, the anemia may indicate concealed bleeding that becomes manifest with anticoagulation therapy.

The use of IL-6 as a predictor of anticoagulation-related bleeding remains controversial. A large cohort study in AF patients found that IL-6 was independently associated with bleeding following adjustment for clinical risk factors and other biomarkers (troponin, NT-proBNP, and cystatinC) (59). Meanwhile, although a separate large cohort study initially demonstrated the relationship between IL-6 and bleeding, the results were not statistically significant once other biomarkers were taken into account (172). Neither of these studies found CRP to be important in the relationship with bleeding.

Similar to the stroke findings as discussed above, the study by Janion-Sadowska et al. found no association between thrombocytopenia (platelet count $<100 \times 10^{9} / \mathrm{L}$ ) and risk of bleeding (53). In contrast, Park et al. reported that patients with a platelet count $<100 \times 10^{9} / \mathrm{L}$ had a significantly increased risk of bleeding events compared to those with a normal platelet count [HR 2.19 (95\% CI, 1.77-2.70)] (52). Despite limited evidence on the matter, it seems likely that a low platelet count could increase the risk of bleeding in AF.

In addition to the biomarkers above, there are several others that have been associated with anticoagulation-related bleeding including vWF, high-sensitivity troponin, and growth differentiation factor-15 (marker of oxidative stress). Roldan et al. showed that patients with high levels of vWF had a 4.5 -fold increased risk of major bleeding (69). Using the ARISTOTLE cohort, Hijazi et al. demonstrated that both high-sensitivity troponin and growth differentiation factor-15 were the strongest predictors of major bleeding when compared to traditional risk factors such as age, hemoglobin, previous bleeding, congestive heart failure, previous stroke or TIA, hypertension, and diabetes mellitus (129). Studies on NT-proBNP have not found it to be useful for predicting anticoagulation-related bleeding $(62,65,66)$. Overall, there is limited research to support the "real world" role of these biomarkers in relation to bleeding risk assessment, given that bleeding risk is dynamic and changes with addressing modifiable risks, and that many biomarkers are non-specific and likely to reflect a sick patient or "sick heart."

\section{Genetic Markers}

Polymorphism of cytochrome P450 2C9 has been linked to an increased risk of major bleeding through its effects on the metabolism and action of warfarin (173). It may also have important implications on warfarin dose requirements (174).
However, as mentioned above, there is currently limited evidence on the role for genetic markers in AF.

\section{LIMITATIONS OF RISK SCORES}

Risk scores are useful as they provide a rapid tool to guide treatment decisions in $\mathrm{AF}$ and highlight bleeding risk factors that deserve attention. However, it is important to recognize that the risk scores in AF have been simplified to provide physicians with a reliable yet useable tool for daily clinical practice. As a result, most are subject to several limitations and are at best, only modestly robust at predicting individual stroke risk (175).

First, not all risk factors may be included in certain risk scores. Second, they use a "one size fits all" approach and do not account for the heterogenous nature within the AF population. Third, they fail to adequately consider the differential weight of individual risk factors. Fourth, they fail to consider the degree or severity of individual risk factors. Fifth, many risk scores were developed using older definition of diseases that may have subsequently evolved over time. Finally, studies have often correlated stroke occurrences during long periods of follow-up to risk factors measured at baseline, and risk changes with increasing age and incident risk factors. Indeed, recent attention has been directed toward the dynamic nature of risk profiles in AF patients (176178). Chao et al. found the majority of patients with $\mathrm{AF}$ (89.4\%) developed $\geq 1$ new risk factor(s) prior to presenting with an ischemic stroke (178). Indeed, a change in $\mathrm{CHA}_{2} \mathrm{DS}_{2}$ VASc score was demonstrated to be strongly predictive of ischemic stroke. The study highlights the importance of regular stroke risk assessments in AF. Therefore, stroke and bleeding risk stratification should be undertaken by clinicians as a continuous process with specific focus on preventing the development of additional risk factors. Furthermore, in addition to the dynamic nature of risk, therapeutic options for AF are expanding. As more effective and safer therapies are introduced, we may need to re-evaluate the threshold for initiating anticoagulation.

\section{CONCLUSION}

In conclusion, there are a variety of clinical, electrical, biological, and genetic markers to guide stroke and bleeding risk assessments in AF. Furthermore, risk schemas provide a structured, standardized, and rapid tool for this purpose.

\section{AUTHOR CONTRIBUTIONS}

WD drafted the manuscript. SH, DG, DL, and GL provided critical appraisal. All authors approved the final version of the manuscript and agree to be accountable for the accuracy or integrity of the manuscript. 


\section{REFERENCES}

1. Chugh SS, Havmoeller R, Narayanan $K$, Singh D, Rienstra $M$, Benjamin EJ, et al. Worldwide epidemiology of atrial fibrillation: a global burden of disease 2010 study. Circulation. (2014) 129:837-47. doi: 10.1161/CIRCULATIONAHA.113.005119

2. Benjamin EJ, Wolf PA, D’Agostino RB, Silbershatz H, Kannel WB, Levy D. Impact of atrial fibrillation on the risk of death: The Framingham Heart Study. Circulation. (1998) 98:946-52. doi: 10.1161/01.CIR.98.10.946

3. Stewart S, Hart CL, Hole DJ, McMurray JJ. A population-based study of the long-term risks associated with atrial fibrillation: 20-year follow-up of the Renfrew/Paisley study. Am J Med. (2002) 113:35964. doi: 10.1016/S0002-9343(02)01236-6

4. Thrall G, Lane D, Carroll D, Lip GYH. Quality of life in patients with atrial fibrillation: a systematic review. Am J Med. (2006) 119:448.e119. doi: 10.1016/j.amjmed.2005.10.057

5. Vermond RA, Geelhoed B, Verweij N, Tieleman RG, Van der Harst $\mathrm{P}$, Hillege HL, et al. Incidence of atrial fibrillation and relationship with cardiovascular events, heart failure, and mortality a communitybased study from the Netherlands. J Am Coll Cardiol. (2015) 66:10007. doi: 10.1016/j.jacc.2015.06.1314

6. Stewart S, Murphy NF, Walker A, McGuire A, McMurray JJ. Cost of an emerging epidemic: an economic analysis of atrial fibrillation in the UK. Heart. (2004) 90:286-92. doi: 10.1136/hrt.2002.008748

7. Kim MH, Johnston SS, Chu B-C, Dalal MR, Schulman KL. Estimation of total incremental health care costs in patients with atrial fibrillation in the United States. Circ Cardiovasc Qual Outcomes. (2011) 4:31320. doi: 10.1161/CIRCOUTCOMES.110.958165

8. Lip GYH, Kakar P, Watson T. Atrial fibrillation - the growing epidemic. Heart. (2007) 93:542-3. doi: 10.1136/hrt.2006.110791

9. Morillo CA, Banerjee A, Perel P, Wood D, Jouven X. Atrial fibrillation: the current epidemic. J Geriatr Cardiol. (2017) 14:195-203. doi: 10.11909/j.issn.1671-5411.2017.03.011

10. Miyasaka Y, Barnes ME, Gersh BJ, Cha SS, Bailey KR, Abhayaratna WP, et al. Secular trends in incidence of atrial fibrillation in Olmsted County, Minnesota, 1980 to 2000, and implications on the projections for future prevalence. Circulation. (2006) 114:119-25. doi: 10.1161/CIRCULATIONAHA.105.595140

11. Go AS, Hylek EM, Phillips KA, Chang Y, Henault LE, Selby J V, et al. Prevalence of diagnosed atrial fibrillation in adults: national implications for rhythm management and stroke prevention: the AnTicoagulation and Risk Factors in Atrial Fibrillation (ATRIA) Study. JAMA. (2001) 285:23705. doi: $10.1001 /$ jama.285.18.2370

12. Krijthe BP, Kunst A, Benjamin EJ, Lip GYH, Franco OH, Hofman A, et al. Projections on the number of individuals with atrial fibrillation in the European Union, from 2000 to 2060. Eur Heart J. (2013) 34:274651. doi: 10.1093/eurheartj/eht280

13. Wolf PA, Dawber TR, Thomas HEJ, Kannel WB. Epidemiologic assessment of chronic atrial fibrillation and risk of stroke: the Framingham study. Neurology. (1978) 28:973-7. doi: 10.1212/WNL.28.10.973

14. Britton M, Gustafsson C. Non-rheumatic atrial fibrillation as a risk factor for stroke. Stroke. (1985) 16:182-8. doi: 10.1161/01.STR.16.2.182

15. Lin HJ, Wolf PA, Kelly-Hayes M, Beiser AS, Kase CS, Benjamin EJ, et al. Stroke severity in atrial fibrillation. The Framingham Study. Stroke. (1996) 27:1760-4. doi: 10.1161/01.STR.27.10.1760

16. Fox KAA, Lucas JE, Pieper KS, Bassand J-P, Camm AJ, Fitzmaurice DA, et al. Improved risk stratification of patients with atrial fibrillation: an integrated GARFIELD-AF tool for the prediction of mortality, stroke and bleed in patients with and without anticoagulation. BMJ Open. (2017) 7:e017157. doi: 10.1136/bmjopen-2017-017157

17. Piccini JP, Stevens SR, Chang Y, Singer DE, Lokhnygina Y, Go AS, et al. Renal dysfunction as a predictor of stroke and systemic embolism in patients with nonvalvular atrial fibrillation: validation of the R2CHADS2 index in the ROCKET AF. Circulation. (2013) 127:224-32. doi: 10.1161/CIRCULATIONAHA.112.107128

18. Lip GY, Nieuwlaat R, Pisters R, Lane DA, Crijns HJ. Refining clinical risk stratification for predicting stroke and thromboembolism in atrial fibrillation using a novel risk factor-based approach: the euro heart survey on atrial fibrillation. Chest. (2010) 137:263-72. doi: 10.1378/ches t.09-1584

19. Hart RG, Stroke Risk in Atrial Fibrillation Working Group. Comparison of 12 risk stratification schemes to predict stroke in patients with nonvalvular atrial fibrillation. Stroke. (2008) 39:1901-10. doi: 10.1161/STROKEAHA.107.501825

20. Kirchhof P, Benussi S, Kotecha D, Ahlsson A, Atar D, Casadei B, et al. 2016 ESC guidelines for the management of atrial fibrillation developed in collaboration with EACTS. Eur Heart J. (2016) 37:2893962. doi: 10.5603/KP.2016.0172

21. January CT, Wann LS, Alpert JS, Calkins H, Cigarroa JE, Cleveland JC Jr, et al. 2014 AHA/ACC/HRS guideline for the management of patients with atrial fibrillation: a report of the American College of Cardiology/American Heart Association Task Force on Practice Guidelines and the Heart Rhythm Society. J Am Coll Cardiol. (2014) 64:e1-76. doi: 10.1016/j.jacc.2014.03.022

22. National Institute for Health and Care Excellence. Guideline on Atrial Fibrillation: Management. (2014). p. 1-45. Available online at: https://www. nice.org.uk/guidance/cg180/resources/atrial-fibrillation-management-pdf35109805981381 (accessed September 3, 2019).

23. Lip GYH, Banerjee A, Boriani G, Chiang CE, Fargo R, Freedman B, et al. Antithrombotic therapy for atrial fibrillation: CHEST guideline and expert panel report. Chest. (2018) 154:1121-201. doi: 10.1016/j.chest.2018.07.040

24. Chiang C-E, Okumura K, Zhang S, Chao T-F, Siu C-W, Wei Lim T, et al. 2017 consensus of the Asia Pacific Heart Rhythm Society on stroke prevention in atrial fibrillation. J Arrhythmia. (2017) 33:34567. doi: 10.1016/j.joa.2017.05.004

25. Friberg L, Rosenqvist M, Lip GYH. Evaluation of risk stratification schemes for Ischemic stroke and bleeding in 182678 patients with atrial fibrillation: the Swedish Atrial Fibrillation cohort study. Eur Heart J. (2012) 33:150010. doi: 10.1093 /eurheartj/ehr488

26. Risk factors for stroke and efficacy of antithrombotic therapy in atrial fibrillation. Analysis of pooled data from five randomized controlled trials. Arch Intern Med. (1994) 154:1449-57. doi: 10.1001/archinte.154.13.1449

27. Lip GYH, Skjoth F, Rasmussen LH, Larsen TB. Oral anticoagulation, aspirin, or no therapy in patients with nonvalvular AF with 0 or 1 stroke risk factor based on the CHA2DS2-VASc score. J Am Coll Cardiol. (2015) 65:138594. doi: 10.1016/j.jacc.2015.01.044

28. Stroke Risk in Atrial Fibrillation Working Group. Independent predictors of stroke in patients with atrial fibrillation: a systematic review. Neurology. (2007) 69:546-54. doi: 10.1212/01.wnl.0000267275.68538.8d

29. Olesen JB, Fauchier L, Lane DA, Taillandier S, Lip GYH. Risk factors for stroke and thromboembolism in relation to age among patients with atrial fibrillation: the Loire Valley Atrial Fibrillation Project. Chest. (2012) 141:147-53. doi: 10.1378/chest.11-0862

30. Fang MC, Singer DE, Chang Y, Hylek EM, Henault LE, Jensvold NG, et al. Gender differences in the risk of ischemic stroke and peripheral embolism in atrial fibrillation: the AnTicoagulation and Risk factors In Atrial fibrillation (ATRIA) study. Circulation. (2005) 112:168791. doi: 10.1161/CIRCULATIONAHA.105.553438

31. Poli D, Antonucci E, Grifoni E, Abbate R, Gensini GF, Prisco D. Gender differences in stroke risk of atrial fibrillation patients on oral anticoagulant treatment. Thromb Haemost. (2009) 101:938-42. doi: 10.1160/TH08-10-0635

32. Renoux C, Coulombe J, Suissa S. Revisiting sex differences in outcomes in non-valvular atrial fibrillation: a population-based cohort study. Eur Heart J. (2017) 38:1473-9. doi: 10.1093/eurheartj/ehw613

33. Nielsen PB, Skjoth F, Overvad TF, Larsen TB, Lip GYH. Female sex is a risk modifier rather than a risk factor for stroke in atrial fibrillation: should we use a CHA2DS2-VA score rather than CHA2DS2-VASc? Circulation. (2018) 137:832-40. doi: 10.1161/CIRCULATIONAHA.117.029081

34. Chu S-Y, Jiang J, Wang Y-L, Sheng Q-H, Zhou J, Ding Y-S. Pacemakerdetected atrial fibrillation burden and risk of ischemic stroke or thromboembolic events-a cohort study. Hear Lung. (2020) 49:66-72. doi: 10.1016/j.hrtlng.2019.07.007

35. Go AS, Reynolds K, Yang J, Gupta N, Lenane J, Sung SH, et al. Association of burden of atrial fibrillation with risk of ischemic stroke in adults with paroxysmal atrial fibrillation: the KP-RHYTHM Study. JAMA Cardiol. (2018) 3:601-8. doi: 10.1001/jamacardio.2018.1176 
36. Link MS, Giugliano RP, Ruff CT, Scirica BM, Huikuri H, Oto A, et al. Stroke and mortality risk in patients with various patterns of atrial fibrillation: results from the ENGAGE AF-TIMI 48 Trial (effective anticoagulation with factor $\mathrm{Xa}$ next generation in atrial fibrillation-thrombolysis in myocardial infarction 48). Circ Arrhythmia Electrophysiol. (2017) 10:17. doi: 10.1161/CIRCEP.116.004267

37. Boriani G, Glotzer TV, Santini M, West TM, De Melis M, Sepsi M, et al. Device-detected atrial fibrillation and risk for stroke: an analysis of $>10,000$ patients from the SOS AF project (stroke prevention strategies based on atrial fibrillation information from implanted devices). Eur Heart J. (2014) 35:508-16. doi: 10.1093/eurheartj/eht491

38. Healey JS, Connolly SJ, Gold MR, Israel CW, Van Gelder IC, Capucci A, et al. Subclinical atrial fibrillation and the risk of stroke. N Engl J Med. (2012) 366:120-9. doi: 10.1056/NEJMoa1105575

39. Friberg L, Hammar N, Rosenqvist M. Stroke in paroxysmal atrial fibrillation: report from the stockholm cohort of atrial fibrillation. Eur Heart J. (2010) 31:967-75. doi: 10.1093/eurheartj/ehn599

40. Yilmaz MB, Guray Y, Guray U, Cay S, Caldir V, Biyikoglu SF, et al. Fine vs. coarse atrial fibrillation: which one is more risky? Cardiology. (2007) 107:193-6. doi: 10.1159/000095416

41. Hohnloser SH, Pajitnev D, Pogue J, Healey JS, Pfeffer MA, Yusuf $S$, et al. Incidence of stroke in paroxysmal versus sustained atrial fibrillation in patients taking oral anticoagulation or combined antiplatelet therapy. An ACTIVE W Substudy. J Am Coll Cardiol. (2007) 50:215661. doi: 10.1016/j.jacc.2007.07.076

42. Capucci A, Santini M, Padeletti L, Gulizia M, Botto G, Boriani G, et al. Monitored atrial fibrillation duration predicts arterial embolic events in patients suffering from bradycardia and atrial fibrillation implanted with antitachycardia pacemakers. J Am Coll Cardiol. (2005) 46:191320. doi: 10.1016/j.jacc.2005.07.044

43. Glotzer TV, Hellkamp AS, Zimmerman J, Sweeney MO, Yee R, Marinchak $\mathrm{R}$, et al. Atrial high rate episodes detected by pacemaker diagnostics predict death and stroke: report of the atrial diagnostics ancillary study of the MOde Selection Trial (MOST). Circulation. (2003) 107:16149. doi: 10.1161/01.CIR.0000057981.70380.45

44. Hart RG, Pearce LA, Rothbart RM, McAnulty JH, Asinger RW, Halperin JL. Stroke with intermittent atrial fibrillation: incidence and predictors during aspirin therapy. J Am Coll Cardiol. (2000) 35:1837. doi: 10.1016/S0735-1097(99)00489-1

45. Hughes M, Lip GYH. Stroke and thromboembolism in atrial fibrillation: a systematic review of stroke risk factors, risk stratification schema and cost effectiveness data. Thromb Haemost. (2008) 99:295-304. doi: 10.1160/TH07-08-0508

46. Ganesan AN, Chew DP, Hartshorne T, Selvanayagam JB, Aylward PE, Sanders $\mathrm{P}$, et al. The impact of atrial fibrillation type on the risk of thromboembolism, mortality, and bleeding: a systematic review and metaanalysis. Eur Heart J. (2016) 37:1591-602. doi: 10.1093/eurheartj/ehw007

47. Palomaki A, Mustonen P, Hartikainen JEK, Nuotio I, Kiviniemi T, Ylitalo A, et al. Strokes after cardioversion of atrial fibrillation-The FibStroke study. Int J Cardiol. (2016) 203:269-73. doi: 10.1016/j.ijcard.2015.10.168

48. Weigner MJ, Caulfield TA, Danias PG, Silverman DI, Manning WJ. Risk for clinical thromboembolism associated with conversion to sinus rhythm in patients with atrial fibrillation lasting less than 48 hours. Ann Intern Med. (1997) 126:615-20. doi: 10.7326/0003-4819-126-8-199704150-00005

49. Michael JA, Stiell IG, Agarwal S, Mandavia DP. Cardioversion of paroxysmal atrial fibrillation in the emergency department. Ann Emerg Med. (1999) 33:379-87. doi: 10.1016/S0196-0644(99)70300-8

50. Khan IA. Atrial stunning: basics and clinical considerations. Int J Cardiol. (2003) 92:113-28. doi: 10.1016/S0167-5273(03)00107-4

51. Brambatti M, Connolly SJ, Gold MR, Morillo CA, Capucci A, Muto C, et al. Temporal relationship between subclinical atrial fibrillation and embolic events. Circulation. (2014) 129:20949. doi: 10.1161/CIRCULATIONAHA.113.007825

52. Park J, Cha M-J, Choi Y-J, Lee E, Moon I, Kwak S, et al. Prognostic efficacy of platelet count in patients with nonvalvular atrial fibrillation. Heart Rhythm. (2019) 16:197-203. doi: 10.1016/j.hrthm.201 8.08 .023
53. Janion-Sadowska A, Papuga-Szela E, Lukaszuk R, Chrapek M, Undas A. Non-vitamin $\mathrm{K}$ antagonist oral anticoagulants in patients with atrial fibrillation and thrombocytopenia. J Cardiovasc Pharmacol. (2018) 72:15360. doi: 10.1097/FJC.0000000000000607

54. Rivera-Caravaca JM, Roldan V, Romera M, Esteve-Pastor MA, Valdes M, Lip GYH, et al. Soluble fibrin monomer complex and prediction of cardiovascular events in atrial fibrillation: the observational murcia atrial fibrillation project. J Gen Intern Med. (2018) 33:847-54. doi: 10.1007/s11606-017-4279-4

55. You L-R, Tang M. The association of high D-dimer level with high risk of ischemic stroke in nonvalvular atrial fibrillation patients: a retrospective study. Medicine. (2018) 97:e12622. doi: 10.1097/MD.0000000000012622

56. Ancedy Y, Berthelot E, Lang S, Ederhy S, Boyer-Chatenet L, Di Angelantonio $\mathrm{E}$, et al. Is von Willebrand factor associated with stroke and death at midterm in patients with non-valvular atrial fibrillation? Arch Cardiovasc Dis. (2018) 111:357-69. doi: 10.1016/j.acvd.2017.08.004

57. Hayashi K, Tsuda T, Nomura A, Fujino N, Nohara A, Sakata K, et al. Impact of B-type natriuretic peptide level on risk stratification of thromboembolism and death in patients with nonvalvular atrial fibrillation- the Hokuriku-Plus AF registry. Circ J. (2018) 82:1271-8. doi: 10.1253/circj.CJ-17-1085

58. Choi S-W, Kim B-B, Choi D-H, Park G, Shin BC, Song H, et al. Stroke or left atrial thrombus prediction using antithrombin III and mean platelet volume in patients with nonvalvular atrial fibrillation. Clin Cardiol. (2017) 40:1013-9. doi: 10.1002/clc.22759

59. Aulin J, Siegbahn A, Hijazi Z, Ezekowitz MD, Andersson U, Connolly SJ, et al. Interleukin-6 and C-reactive protein and risk for death and cardiovascular events in patients with atrial fibrillation. Am Heart J. (2015) 170:115160. doi: 10.1016/j.ahj.2015.09.018

60. Pignatelli P, Pastori D, Carnevale R, Farcomeni A, Cangemi R, Nocella $\mathrm{C}$, et al. Serum NOX2 and urinary isoprostanes predict vascular events in patients with atrial fibrillation. Thromb Haemost. (2015) 113:61724. doi: 10.1160/TH14-07-0571

61. Banerjee A, Fauchier L, Vourc'H P, Andres CR, Taillandier S, Halimi JM, et al. A prospective study of estimated glomerular filtration rate and outcomes in patients with atrial fibrillation: the Loire Valley Atrial Fibrillation Project. Chest. (2014) 145:1370-82. doi: 10.1378/chest.13-2103

62. Roldan V, Vilchez JA, Manzano-Fernandez S, Jover E, Galvez J, Puche CM, et al. Usefulness of $\mathrm{N}$-terminal pro-B-type natriuretic peptide levels for stroke risk prediction in anticoagulated patients with atrial fibrillation. Stroke. (2014) 45:696-701. doi: 10.1161/STROKEAHA.113.003338

63. Apostolakis S, Guo Y, Lane DA, Buller H, Lip GYH. Renal function and outcomes in anticoagulated patients with nonvalvular atrial fibrillation: the AMADEUS trial. Eur Heart J. (2013) 34:3572-9. doi: 10.1093/eurheartj/eht328

64. Krishnamoorthy S, Khoo CW, Lim HS, Lane DA, Pignatelli P, Basili S, et al. Prognostic role of plasma von Willebrand factor and soluble Eselectin levels for future cardiovascular events in a "real-world" community cohort of patients with atrial fibrillation. Eur J Clin Invest. (2013) 43:10328. doi: $10.1111 /$ eci.12140

65. Hijazi Z, Wallentin L, Siegbahn A, Andersson U, Christersson C, Ezekowitz $\mathrm{J}$, et al. N-terminal pro-B-type natriuretic peptide for risk assessment in patients with atrial fibrillation: insights from the ARISTOTLE Trial (Apixaban for the Prevention of Stroke in Subjects With Atrial Fibrillation). J Am Coll Cardiol. (2013) 61:2274-84. doi: 10.1016/j.jacc.2012.11.082

66. Hijazi Z, Oldgren J, Andersson U, Connolly SJ, Ezekowitz MD, Hohnloser $\mathrm{SH}$, et al. Cardiac biomarkers are associated with an increased risk of stroke and death in patients with atrial fibrillation: a randomized evaluation of long-term anticoagulation therapy (RE-LY) substudy. Circulation. (2012) 125:1605-16. doi: 10.1161/CIRCULATIONAHA.111.038729

67. Roldan V, Marin F, Diaz J, Gallego P, Jover E, Romera M, et al. High sensitivity cardiac troponin $\mathrm{T}$ and interleukin- 6 predict adverse cardiovascular events and mortality in anticoagulated patients with atrial fibrillation. J Thromb Haemost. (2012) 10:1500-7. doi: 10.1111/j.1538-7836.2012.04812.x

68. Ehrlich JR, Kaluzny M, Baumann S, Lehmann R, Hohnloser SH. Biomarkers of structural remodelling and endothelial dysfunction for prediction of cardiovascular events or death in patients with atrial fibrillation. Clin Res Cardiol. (2011) 100:1029-36. doi: 10.1007/s00392-011-0337-9 
69. Roldan V, Marin F, Muina B, Torregrosa JM, Hernandez-Romero D, Valdes M, et al. Plasma von Willebrand factor levels are an independent risk factor for adverse events including mortality and major bleeding in anticoagulated atrial fibrillation patients. J Am Coll Cardiol. (2011) 57:2496504. doi: 10.1016/j.jacc.2010.12.033

70. Ha S-I, Choi D-H, Ki Y-J, Yang J-S, Park G, Chung J-W, et al. Stroke prediction using mean platelet volume in patients with atrial fibrillation. Platelets. (2011) 22:408-14. doi: 10.3109/09537104.2011.560306

71. Sadanaga T, Kohsaka S, Mitamura H, Ogawa S. Elevated B-type natriuretic peptide level as a marker of subsequent thromboembolic events in patients with atrial fibrillation. Heart Vessels. (2011) 26:5305. doi: 10.1007/s00380-010-0084-2

72. Sadanaga T, Sadanaga M, Ogawa S. Evidence that D-dimer levels predict subsequent thromboembolic and cardiovascular events in patients with atrial fibrillation during oral anticoagulant therapy. J Am Coll Cardiol. (2010) 55:2225-31. doi: 10.1016/j.jacc.2009.12.049

73. Go AS, Fang MC, Udaltsova N, Chang Y, Pomernacki NK, Borowsky $\mathrm{L}$, et al. Impact of proteinuria and glomerular filtration rate on risk of thromboembolism in atrial fibrillation: the anticoagulation and risk factors in atrial fibrillation (ATRIA) study. Circulation. (2009) 119:13639. doi: 10.1161/CIRCULATIONAHA.108.816082

74. Pinto A, Tuttolomondo A, Casuccio A, Di Raimondo D, Di Sciacca R, Arnao $\mathrm{V}$, et al. Immuno-inflammatory predictors of stroke at follow-up in patients with chronic non-valvular atrial fibrillation (NVAF). Clin Sci. (2009) 116:781-9. doi: 10.1042/CS20080372

75. Ferro D, Loffredo L, Polimeni L, Fimognari F, Villari P, Pignatelli P, et al. Soluble CD40 ligand predicts ischemic stroke and myocardial infarction in patients with nonvalvular atrial fibrillation. Arterioscler Thromb Vasc Biol. (2007) 27:2763-8. doi: 10.1161/ATVBAHA.107.152777

76. Nozawa T, Inoue H, Hirai T, Iwasa A, Okumura K, Lee J-D, et al. D-dimer level influences thromboembolic events in patients with atrial fibrillation. Int J Cardiol. (2006) 109:59-65. doi: 10.1016/j.ijcard.2005.05.049

77. Conway DS, Buggins P, Hughes E, Lip GYH. Prognostic significance of raised plasma levels of interleukin-6 and C-reactive protein in atrial fibrillation. Am Heart J. (2004) 148:462-6. doi: 10.1016/j.ahj.2004.01.026

78. Vene N, Mavri A, Kosmelj K, Stegnar M. High D-dimer levels predict cardiovascular events in patients with chronic atrial fibrillation during oral anticoagulant therapy. Thromb Haemost. (2003) 90:116372. doi: 10.1160/TH03-06-0363

79. Feinberg WM, Pearce LA, Hart RG, Cushman M, Cornell ES, Lip GYH, et al. Markers of thrombin and platelet activity in patients with atrial fibrillation: correlation with stroke among 1531 participants in the stroke prevention in atrial fibrillation III study. Stroke. (1999) 30:254753. doi: 10.1161/01.STR.30.12.2547

80. Roffi M, Patrono C, Collet J-P, Mueller C, Valgimigli M, Andreotti F, et al. 2015 ESC Guidelines for the management of acute coronary syndromes in patients presenting without persistent ST-segment elevation: Task Force for the Management of Acute Coronary Syndromes in Patients Presenting without Persistent ST-Segment Elevation of the European Society of Cardiology (ESC). Eur Heart J. (2016) 37:267315. doi: 10.1093/eurheartj/ehv320

81. Ponikowski P, Voors AA, Anker SD, Bueno H, Cleland JGF, Coats AJS, et al. 2016 ESC Guidelines for the diagnosis and treatment of acute and chronic heart failure: The Task Force for the diagnosis and treatment of acute and chronic heart failure of the European Society of Cardiology (ESC) developed with the special contribution of Heart Failure Association (HFA) of the ESC. Eur Heart J. (2016) 37:2129-200. doi: 10.1093/eurheartj/ ehw128

82. Goetze JP, Friis-Hansen L, Rehfeld JF, Nilsson B, Svendsen JH. Atrial secretion of B-type natriuretic peptide. Eur Heart J. (2006) 27:164850. doi: 10.1093/eurheartj/ehl109

83. Yamada T, Murakami Y, Okada T, Okamoto M, Shimizu T, Toyama J, et al. Plasma atrial natriuretic peptide and brain natriuretic peptide levels after radiofrequency catheter ablation of atrial fibrillation. Am J Cardiol. (2006) 97:1741-4. doi: 10.1016/j.amjcard.2005.12.071

84. Wozakowska-Kapłon B. Effect of sinus rhythm restoration on plasma brain natriuretic peptide in patients with atrial fibrillation. Am J Cardiol. (2004) 93:1555-8. doi: 10.1016/j.amjcard.2004.03.013
85. Mantymaa P, Vuolteenaho O, Marttila M, Ruskoaho H. Atrial stretch induces rapid increase in brain natriuretic peptide but not in atrial natriuretic peptide gene expression in vitro. Endocrinology. (1993) 133:14703. doi: 10.1210/endo.133.3.8365376

86. Transesophageal echocardiographic correlates of thromboembolism in high-risk patients with nonvalvular atrial fibrillation. The Stroke Prevention in Atrial Fibrillation Investigators Committee on Echocardiography. Ann Intern Med. (1998) 128:63947. doi: 10.7326/0003-4819-128-8-199804150-00005

87. Natale M, Behnes M, Kim S-H, Hoffmann J, Reckord N, Hoffmann U, et al. High sensitivity troponin $\mathrm{T}$ and I reflect left atrial function being assessed by cardiac magnetic resonance imaging. Ann Clin Biochem. (2018) 55:264-75. doi: 10.1177/0004563217714004

88. Zeng W-TT, Sun X-TT, Tang K, Mei W-YY, Liu L-JJ, Xu Q, et al. Risk of thromboembolic events in atrial fibrillation with chronic kidney disease. Stroke. (2015) 46:157-63. doi: 10.1161/STROKEAHA.114.006881

89. Vazquez E, Sanchez-Perales C, Garcia-Garcia F, Castellano P, Garcia-Cortes M-J, Liebana A, et al. Atrial fibrillation in incident dialysis patients. Kidney Int. (2009) 76:324-30. doi: 10.1038/ki.2009.185

90. Lau YC, Proietti M, Guiducci E, Blann AD, Lip GYH. Atrial fibrillation and thromboembolism in patients with chronic kidney disease. J Am Coll Cardiol. (2016) 68:1452-64. doi: 10.1016/j.jacc.2016.06.057

91. Kizawa S, Ito T, Akamatsu K, Ichihara N, Nogi S, Miyamura M, et al. Chronic kidney disease as a possible predictor of left atrial thrombogenic milieu among patients with nonvalvular atrial fibrillation. Am J Cardiol. (2018) 122:2062-7. doi: 10.1016/j.amjcard.2018.08.058

92. Providencia R, Fernandes A, Paiva L, Faustino A, Barra S, Botelho A, et al. Decreased glomerular filtration rate and markers of left atrial stasis in patients with nonvalvular atrial fibrillation. Cardiology. (2013) 124:310. doi: $10.1159 / 000345434$

93. Kopel T, Kaufman JS, Hamburg N, Sampalis JS, Vita JA, Dember LM. Endothelium-dependent and -independent vascular function in advanced chronic kidney disease. Clin J Am Soc Nephrol. (2017) 12:158894. doi: 10.2215/CJN.12811216

94. Bolton CH, Downs LG, Victory JGG, Dwight JF, Tomson CRV, Mackness MI, et al. Endothelial dysfunction in chronic renal failure: roles of lipoprotein oxidation and pro-inflammatory cytokines. Nephrol Dial Transplant. (2001) 16:1189-97. doi: 10.1093/ndt/16.6.1189

95. Bartnicki P, Kowalczyk M, Franczyk-Skora B, Baj Z, Rysz J. Evaluation of endothelial (dys) function, left ventricular structure and function in patients with chronic kidney disease. Curr Vasc Pharmacol. (2016) 14:3607. doi: 10.2174/1570161114666160112142403

96. Carrero JJ, Kyriazis J, Sonmez A, Tzanakis I, Qureshi AR, Stenvinkel P, et al. Prolactin levels, endothelial dysfunction, and the risk of cardiovascular events and mortality in patients with CKD. Clin J Am Soc Nephrol. (2012) 7:207-15. doi: 10.2215/CJN.06840711

97. Heintz B, Schmidt P, Maurin N, Kirsten R, Nelson K, Wieland D, et al. Endothelin-1 potentiates ADP-induced platelet aggregation in chronic renal failure. Ren Fail. (1994) 16:481-9. doi: 10.3109/08860229409045079

98. Thijs A, Nanayakkara PWB, Ter Wee PM, Huijgens PC, van Guldener C, Stehouwer CDA. Mild-to-moderate renal impairment is associated with platelet activation: a cross-sectional study. Clin Nephrol. (2008) 70:325-31.

99. Landray MJ, Wheeler DC, Lip GYH, Newman DJ, Blann AD, McGlynn FJ, et al. Inflammation, endothelial dysfunction, and platelet activation in patients with chronic kidney disease: the chronic renal impairment in Birmingham (CRIB) study. Am J Kidney Dis. (2004) 43:24453. doi: 10.1053/j.ajkd.2003.10.037

100. Shlipak MG, Fried LF, Crump C, Bleyer AJ, Manolio TA, Tracy $\mathrm{RP}$, et al. Elevations of inflammatory and procoagulant biomarkers in elderly persons with renal insufficiency. Circulation. (2003) 107:8792. doi: 10.1161/01.CIR.0000042700.48769.59

101. Keller C, Katz R, Cushman M, Fried LF, Shlipak M. Association of kidney function with inflammatory and procoagulant markers in a diverse cohort: a cross-sectional analysis from the multi-ethnic study of atherosclerosis (MESA). BMC Nephrol. (2008) 9:9. doi: 10.1186/1471-2369-9-9

102. Roldan V, Marin F, Manzano-Fernandez S, Fernandez H, Gallego $\mathrm{P}$, Valdes $\mathrm{M}$, et al. Does chronic kidney disease improve the predictive value of the CHADS2 and CHA2DS2-VASc stroke 
stratification risk scores for atrial fibrillation? Thromb Haemost. (2013) 109:956-60. doi: 10.1160/TH13-01-0054

103. Banerjee A, Fauchier L, Vourc'h P, Andres CR, Taillandier S, Halimi JM, et al. Renal impairment and ischemic stroke risk assessment in patients with atrial fibrillation: the Loire Valley Atrial Fibrillation Project. J Am Coll Cardiol. (2013) 61:2079-87. doi: 10.1016/j.jacc.2013.02.035

104. He H, Guo J, Zhang A. The value of urine albumin in predicting thromboembolic events for patients with non-valvular atrial fibrillation. Int J Cardiol. (2016) 221:827-30. doi: 10.1016/j.ijcard.2016.07.145

105. Gigante A, Barbano B, Sardo L, Martina P, Gasperini ML, Labbadia R, et al. Hypercoagulability and nephrotic syndrome. Curr Vasc Pharmacol. (2014) 12:512-7. doi: 10.2174/157016111203140518172048

106. Pastori D, Pignatelli P, Farcomeni A, Cangemi R, Hiatt WR, Bartimoccia S, et al. Urinary 11-dehydro-thromboxane B2 is associated with cardiovascular events and mortality in patients with atrial fibrillation. Am Heart J. (2015) 170:490-7.e1. doi: 10.1016/j.ahj.2015.05.011

107. Dakay K, Chang AD, Hemendinger M, Cutting S, McTaggart RA, Jayaraman MV, et al. Left atrial enlargement and anticoagulation status in patients with acute ischemic stroke and atrial fibrillation. J Stroke Cerebrovasc Dis. (2018) 27:192-7. doi: 10.1016/j.jstrokecerebrovasdis.2017.08.025

108. Hamatani Y, Ogawa H, Takabayashi K, Yamashita Y, Takagi D, Esato M, et al. Left atrial enlargement is an independent predictor of stroke and systemic embolism in patients with non-valvular atrial fibrillation. Sci Rep. (2016) 6:31042. doi: 10.1038/srep31042

109. Kong B, Liu Y, Hu H, Wang L, Fan Y, Mei Y, et al. Left atrial appendage morphology in patients with atrial fibrillation in China: implications for stroke risk assessment from a single center study. Chin Med J. (2014) 127:4210-4.

110. Khurram IM, Dewire J, Mager M, Maqbool F, Zimmerman SL, Zipunnikov $\mathrm{V}$, et al. Relationship between left atrial appendage morphology and stroke in patients with atrial fibrillation. Heart Rhythm. (2013) 10:18439. doi: 10.1016/j.hrthm.2013.09.065

111. Kimura T, Takatsuki S, Inagawa K, Katsumata Y, Nishiyama T, Nishiyama $\mathrm{N}$, et al. Anatomical characteristics of the left atrial appendage in cardiogenic stroke with low CHADS2 scores. Heart Rhythm. (2013) 10:9215. doi: 10.1016/j.hrthm.2013.01.036

112. Di Biase L, Santangeli P, Anselmino M, Mohanty P, Salvetti I, Gili S, et al. Does the left atrial appendage morphology correlate with the risk of stroke in patients with atrial fibrillation? Results from a multicenter study. J Am Coll Cardiol. (2012) 60:531-8. doi: 10.1016/j.jacc.2012.04.032

113. Beinart R, Heist EK, Newell JB, Holmvang G, Ruskin JN, Mansour M. Left atrial appendage dimensions predict the risk of Stroke/TIA in patients with atrial fibrillation. J Cardiovasc Electrophysiol. (2011) 22:105. doi: 10.1111/j.1540-8167.2010.01854.x

114. Goldman ME, Pearce LA, Hart RG, Zabalgoitia M, Asinger RW, Safford R, et al. Pathophysiologic correlates of thromboembolism in nonvalvular atrial fibrillation: I. Reduced flow velocity in the left atrial appendage (The stroke prevention in atrial fibrillation [SPAF-III] study). J Am Soc Echocardiogr. (1999) 12:1080-7. doi: 10.1016/S0894-7317(99)70105-7

115. Zabalgoitia M, Halperin JL, Pearce LA, Blackshear JL, Asinger RW, Hart RG. Transesophageal echocardiographic correlates of clinical risk of thromboembolism in nonvalvular atrial fibrillation. Stroke Prevention in Atrial Fibrillation III Investigators. J Am Coll Cardiol. (1998) 31:16226. doi: 10.1016/S0735-1097(98)00146-6

116. Leung DYC, Black IW, Cranney GB, Hopkins AP, Walsh WF. Prognostic implications of left atrial spontaneous echo contrast in nonvalvular atrial fibrillation. J Am Coll Cardiol. (1994) 24:755-62. doi: 10.1016/0735-1097(94)90025-6

117. Predictors of thromboembolism in atrial fibrillation: II. Echocardiographic features of patients at risk. The Stroke Prevention in Atrial Fibrillation Investigators. Ann Intern Med. (1992) 116:6-12. doi: 10.7326/0003-4819-116-1-6

118. Benjamin EJ, D’Agostino RB, Belanger AJ, Wolf PA, Levy D. Left atrial size and the risk of stroke and death. The Framingham Heart Study. Circulation. (1995) 92:835-41. doi: 10.1161/01.CIR.92.4.835

119. Akoum N, Fernandez G, Wilson B, Mcgann C, Kholmovski E, Marrouche N. Association of atrial fibrosis quantified using LGE-MRI with atrial appendage thrombus and spontaneous contrast on transesophageal echocardiography in patients with atrial fibrillation. $J$ Cardiovasc Electrophysiol. (2013) 24:1104-9. doi: 10.1111/jce.12199

120. Gretarsdottir S, Thorleifsson G, Manolescu A, Styrkarsdottir U, Helgadottir A, Gschwendtner A, et al. Risk variants for atrial fibrillation on chromosome 4q25 associate with ischemic stroke. Ann Neurol. (2008) 64:402-9. doi: 10.1002/ana.21480

121. Lemmens R, Buysschaert I, Geelen V, Fernandez-Cadenas I, Montaner J, Schmidt $\mathrm{H}$, et al. The association of the $4 \mathrm{q} 25$ susceptibility variant for atrial fibrillation with stroke is limited to stroke of cardioembolic etiology. Stroke. (2010) 41:1850-7. doi: 10.1161/STROKEAHA.110.587980

122. Hu X, Wang J, Li Y, Wu J, Qiao S, Xu S, et al. The $\beta$-fibrinogen gene 455G/A polymorphism associated with cardioembolic stroke in atrial fibrillation with low CHA2DS2-VaSc score. Sci Rep. (2017) 7:17. doi: 10.1038/s41598-017-17537-1

123. Agarwal S, Hachamovitch R, Menon V. Current trial-associated outcomes with warfarin in prevention of stroke in patients with nonvalvular atrial fibrillation: a meta-analysis. Arch Intern Med. (2012) 172:62331. doi: 10.1001/archinternmed.2012.121

124. Fang MC, Go AS, Chang Y, Hylek EM, Henault LE, Jensvold $\mathrm{NG}$, et al. Death and disability from warfarin-associated intracranial and extracranial hemorrhages. Am J Med. (2007) 120:700-5. doi: 10.1016/j.amjmed.2006.07.034

125. Gomez-Outes A, Terleira-Fernandez AI, Calvo-Rojas G, SuarezGea ML, Vargas-Castrillon E. Dabigatran, rivaroxaban, or apixaban versus warfarin in patients with nonvalvular atrial fibrillation: a systematic review and meta-analysis of subgroups. Thrombosis. (2013) 2013:640723. doi: 10.1155/2013/640723

126. Xue Z, Zhang $H$. Non-vitamin $K$ antagonist oral anticoagulants versus warfarin in asians with atrial fibrillation: meta-analysis of randomized trials and real-world studies. Stroke. (2019) 50:2819-28. doi: 10.1161/STROKEAHA.119.026054

127. Palareti G, Leali N, Coccheri S, Poggi M, Manotti C, D’Angelo A, et al. Bleeding complications of oral anticoagulant treatment: an inceptioncohort, prospective collaborative study (ISCOAT). Lancet. (1996) 348:4238. doi: 10.1016/S0140-6736(96)01109-9

128. Beyer-Westendorf J, Ebertz F, Forster K, Gelbricht V, Michalski F, Kohler C, et al. Effectiveness and safety of dabigatran therapy in daily-care patients with atrial fibrillation. Results from the Dresden NOAC Registry. Thromb Haemost. (2015) 113:1247-57. doi: 10.1160/TH14-11-0954

129. Hijazi Z, Oldgren J, Lindback J, Alexander JH, Connolly SJ, Eikelboom JW, et al. The novel biomarker-based ABC (age, biomarkers, clinical history)-bleeding risk score for patients with atrial fibrillation: a derivation and validation study. Lancet. (2016) 387:2302-11. doi: 10.1016/S0140-6736(16)00741-8

130. Fang MC, Go AS, Chang Y, Borowsky LH, Pomernacki NK, Udaltsova $\mathrm{N}$, et al. A new risk scheme to predict warfarin-associated hemorrhage: The ATRIA (Anticoagulation and Risk Factors in Atrial Fibrillation) Study. J Am Coll Cardiol. (2011) 58:395-401. doi: 10.1016/j.jacc.2011. 03.031

131. Gage BF, Yan Y, Milligan PE, Waterman AD, Culverhouse R, Rich MW, et al. Clinical classification schemes for predicting hemorrhage: results from the National Registry of Atrial Fibrillation (NRAF). Am Heart J. (2006) 151:713-9. doi: 10.1016/j.ahj.2005.04.017

132. Zulkifly H, Lip GYH, Lane DA. Bleeding risk scores in atrial fibrillation and venous thromboembolism. Am J Cardiol. (2017) 120:1139-45. doi: 10.1016/j.amjcard.2017.06.058

133. Landefeld CS, Goldman L, Goldman OL, Goldman L. Major bleeding in outpatients treated with warfarin: incidence and prediction by factors known at the start of outpatient therapy. Am J Med. (1989) 87:14452. doi: 10.1016/S0002-9343(89)80689-8

134. Hughes M, Lip GYH. Risk factors for anticoagulation-related bleeding complications in patients with atrial fibrillation: a systematic review. QJM. (2007) 100:599-607. doi: 10.1093/qjmed/hcm076

135. Kuijer PM, Hutten BA, Prins MH, Buller HR. Prediction of the risk of bleeding during anticoagulant treatment for venous thromboembolism. Arch Intern Med. (1999) 159:457-60. doi: 10.1001/archinte.159.5.457 
136. Shireman TI, Mahnken JD, Howard PA, Kresowik TF, Hou Q, Ellerbeck EF. Development of a contemporary bleeding risk model for elderly warfarin recipients. Chest. (2006) 130:1390-6. doi: 10.1378/chest.130.5.1390

137. Schalekamp T, Klungel OH, Souverein PC, de Boer A. Effect of oral antiplatelet agents on major bleeding in users of coumarins. Thromb Haemost. (2008) 100:1076-83. doi: 10.1160/TH08-05-0290

138. Palareti G, Cosmi B. Bleeding with anticoagulation therapy - who is at risk, and how best to identify such patients. Thromb Haemost. (2009) 102:26878. doi: 10.1160/TH08-11-0730

139. Pisters R, Lane DA, Nieuwlaat R, de Vos CB, Crijns HJ, Lip GYH. A novel user-friendly score (HAS-BLED) to assess 1 -year risk of major bleeding in patients with atrial fibrillation: the Euro Heart Survey. Chest. (2010) 138:1093-100. doi: 10.1378/chest.10-0134

140. Gage BF, Birman-Deych E, Kerzner R, Radford MJ, Nilasena DS, Rich MW. Incidence of intracranial hemorrhage in patients with atrial fibrillation who are prone to fall. Am J Med. (2005) 118:6127. doi: 10.1016/j.amjmed.2005.02.022

141. Banerjee A, Clementy N, Haguenoer K, Fauchier L, Lip GYH. Prior history of falls and risk of outcomes in atrial fibrillation: the Loire Valley Atrial Fibrillation Project. Am J Med. (2014) 127:972-8. doi: 10.1016/j.amjmed.2014.05.035

142. Donze J, Clair C, Hug B, Rodondi N, Waeber G, Cornuz J, et al. Risk of falls and major bleeds in patients on oral anticoagulation therapy. Am J Med. (2012) 125:773-8. doi: 10.1016/j.amjmed.2012.01.033

143. Man-Son-Hing M, Nichol G, Lau A, Laupacis A. Choosing antithrombotic therapy for elderly patients with atrial fibrillation who are at risk for falls. Arch Intern Med. (1999) 159:677-85. doi: 10.1001/archinte.1 59.7.677

144. Gitter MJ, Jaeger TM, Petterson TM, Gersh BJ, Silverstein MD. Bleeding and thromboembolism during anticoagulant therapy: a populationbased study in Rochester, Minnesota. Mayo Clin Proc. (1995) 70:72533. doi: $10.4065 / 70.8 .725$

145. Wester JP, de Valk HW, Nieuwenhuis HK, Brouwer CB, van der Graaf $\mathrm{Y}$, Meuwissen OJ, et al. Risk factors for bleeding during treatment of acute venous thromboembolism. Thromb Haemost. (1996) 76:6828. doi: $10.1055 / \mathrm{s}-0038-1650643$

146. Lee AYY, Levine MN, Baker RI, Bowden C, Kakkar AK, Prins M, et al. Lowmolecular-weight heparin versus a coumarin for the prevention of recurrent venous thromboembolism in patients with cancer. N Engl J Med. (2003) 349:146-53. doi: 10.1056/NEJMoa025313

147. Posch F, Konigsbrugge O, Zielinski C, Pabinger I, Ay C. Treatment of venous thromboembolism in patients with cancer: a network metaanalysis comparing efficacy and safety of anticoagulants. Thromb Res. (2015) 136:582-9. doi: 10.1016/j.thromres.2015.07.011

148. Kahale LA, Hakoum MB, Tsolakian IG, Matar CF, Terrenato I, Sperati $\mathrm{F}$, et al. Anticoagulation for the long-term treatment of venous thromboembolism in people with cancer. Cochrane database Syst Rev. (2018) 6:CD006650. doi: 10.1002/14651858.CD006650.pub5

149. Li A, Garcia DA, Lyman GH, Carrier M. Direct oral anticoagulant (DOAC) versus low-molecular-weight heparin (LMWH) for treatment of cancer associated thrombosis (CAT): a systematic review and meta-analysis. Thromb Res. (2019) 173:158-63. doi: 10.1016/j.thromres.2018.02.144

150. Bassand J-P, Accetta G, Al Mahmeed W, Corbalan R, Eikelboom J, Fitzmaurice DA, et al. Risk factors for death, stroke, and bleeding in 28,628 patients from the GARFIELD-AF registry: rationale for comprehensive management of atrial fibrillation. PLoS ONE. (2018) 13:e0191592. doi: 10.1371/journal.pone.0191592

151. Shen AY-J, Yao JF, Brar SS, Jorgensen MB, Chen W. Racial/ethnic differences in the risk of intracranial hemorrhage among patients with atrial fibrillation. J Am Coll Cardiol. (2007) 50:309-15. doi: 10.1016/j.jacc.2007.01.098

152. Klatsky AL, Friedman GD, Sidney S, Kipp H, Kubo A, Armstrong MA. Risk of hemorrhagic stroke in Asian American ethnic groups. Neuroepidemiology. (2005) 25:26-31. doi: 10.1159/000085310

153. Ayala C, Greenlund KJ, Croft JB, Keenan NL, Donehoo RS, Giles WH, et al. Racial/ethnic disparities in mortality by stroke subtype in the United States, 1995-1998. Am J Epidemiol. (2001) 154:105763. doi: 10.1093/aje/154.11.1057
154. Yamashita Y, Morimoto T, Toyota T, Shiomi H, Makiyama T, Ono K, et al. Asian patients versus non-Asian patients in the efficacy and safety of direct oral anticoagulants relative to vitamin $\mathrm{K}$ antagonist for venous thromboembolism: a systemic review and meta-analysis. Thromb Res. (2018) 166:37-42. doi: 10.1016/j.thromres.2018.04.008

155. Patel JP, Roberts LN, Arya R. Anticoagulating obese patients in the modern era. Br J Haematol. (2011) 155:13749. doi: 10.1111/j.1365-2141.2011.08826.x

156. Zhou Y, Ma J, Zhu W. Efficacy and safety of direct oral anticoagulants versus warfarin in patients with atrial fibrillation across bmi categories: a systematic review and meta-analysis. Am J Cardiovasc Drugs. (2020) 20:51-60. doi: 10.1007/s40256-019-00362-4

157. Boonyawat K, Caron F, Li A, Chai-Adisaksopha C, Lim W, Iorio A, et al. Association of body weight with efficacy and safety outcomes in phase III randomized controlled trials of direct oral anticoagulants: a systematic review and meta-analysis. J Thromb Haemost. (2017) 15:132233. doi: 10.1111/jth.13701

158. Proietti M, Guiducci E, Cheli P, Lip GYH. Is there an obesity paradox for outcomes in atrial fibrillation? A systematic review and meta-analysis of non-vitamin K antagonist oral anticoagulant trials. Stroke. (2017) 48:85766. doi: 10.1161/STROKEAHA.116.015984

159. Tittl L, Endig S, Marten S, Reitter A, Beyer-Westendorf I, Beyer-Westendorf J. Impact of BMI on clinical outcomes of NOAC therapy in daily care Results of the prospective Dresden NOAC Registry (NCT01588119). Int J Cardiol. (2018) 262:85-91. doi: 10.1016/j.ijcard.2018.03.060

160. Hart R, Veenstra DL, Boudreau DM, Roth JA. Impact of body mass index and genetics on warfarin major bleeding outcomes in a community setting. Am J Med. (2017) 130:222-8. doi: 10.1016/j.amjmed.2016.08.017

161. Oden A, Fahlen M, Odén A, Fahlén M, Oden A, Fahlen M. Oral anticoagulation and risk of death: a medical record linkage study. $\mathrm{Br}$ Med J. (2002) 325:1073-5. doi: 10.1136/bmj.325.7372.1073

162. Berwaerts J, Dijkhuizen RS, Robb OJ, Webster J. Prediction of functional outcome and in-hospital mortality after admission with oral anticoagulant-related intracerebral hemorrhage. Stroke. (2000) 31:2558-62. doi: 10.1161/01.STR.31.11.2558

163. Sanden P, Renlund H, Svensson PJ, Sjalander A. Bleeding complications and mortality in warfarin-treated VTE patients, dependence of INR variability and iTTR. Thromb Haemost. (2017) 117:27-32. doi: 10.1160/TH16-06-0489

164. Bjorck F, Renlund H, Lip GYH, Wester P, Svensson PJ, Sjalander A. Outcomes in a Warfarin-Treated Population With Atrial Fibrillation. JAMA Cardiol. (2016) 1:172-80. doi: 10.1001/jamacardio.2016.0199

165. Rivera-Caravaca JM, Roldan V, Esteve-Pastor MA, Valdes M, Vicente V, Lip GYH, et al. Importance of time in therapeutic range on bleeding risk prediction using clinical risk scores in patients with atrial fibrillation. Sci Rep. (2017) 7:12066. doi: 10.1038/s41598-017-11683-2

166. Van Den Ham HA, Klungel OH, Leufkens HGM, Van Staa TP. The patterns of anticoagulation control and the risk of stroke, bleeding and mortality in patients with non-valvular atrial fibrillation. J Thromb Haemost. (2013) 11:107-15. doi: 10.1111/jth.12041

167. Hylek EM. Vitamin K antagonists and time in the therapeutic range: implications, challenges, and strategies for improvement. J Thromb Thrombolysis. (2013) 35:333-5. doi: 10.1007/s11239-013-0900-5

168. Rohla M, Weiss TW, Pecen L, Patti G, Siller-Matula JM, Schnabel $\mathrm{RB}$, et al. Risk factors for thromboembolic and bleeding events in anticoagulated patients with atrial fibrillation: the prospective, multicentre observational PREvention oF thromboembolic events - European Registry in Atrial Fibrillation (PREFER in AF). BMJ Open. (2019) 9:e022478. doi: 10.1136/bmjopen-2018-022478

169. Sakuma I, Uchiyama S, Atarashi H, Inoue H, Kitazono T, Yamashita T, et al. Clinical risk factors of stroke and major bleeding in patients with non-valvular atrial fibrillation under rivaroxaban: the EXPAND Study subanalysis. Heart Vessels. (2019) 34:1839-51. doi: 10.1007/s00380-019-01425-x

170. Westenbrink BD, Alings M, Connolly SJ, Eikelboom J, Ezekowitz MD, Oldgren J, et al. Anemia predicts thromboembolic events, bleeding complications and mortality in patients with atrial fibrillation: insights from the RE-LY trial. J Thromb Haemost. (2015) 13:699-707. doi: 10.1111/jth.12874 
171. Weiss HJ, Lages B, Hoffmann T, Turitto VT. Correction of the platelet adhesion defect in delta-storage pool deficiency at elevated hematocrit-possible role of adenosine diphosphate. Blood. (1996) 87:421422. doi: 10.1182/blood.V87.10.4214.bloodjournal87104214

172. Hijazi Z, Aulin J, Andersson U, Alexander JH, Gersh B, Granger CB, et al. Biomarkers of inflammation and risk of cardiovascular events in anticoagulated patients with atrial fibrillation. Heart. (2016) 102:50817. doi: 10.1136/heartjnl-2015-308887

173. Takahashi $\mathrm{H}$, Echizen $\mathrm{H}$. Pharmacogenetics of warfarin elimination and its clinical implications. Clin Pharmacokinet. (2001) 40:587-603. doi: 10.2165/00003088-200140080-00003

174. Lindh JD, Holm L, Andersson ML, Rane A. Influence of CYP2C9 genotype on warfarin dose requirements-a systematic review and meta-analysis. Eur J Clin Pharmacol. (2009) 65:365-75. doi: 10.1007/s00228-008-0584-5

175. Killu AM, Granger CB, Gersh BJ. Risk stratification for stroke in atrial fibrillation: a critique. Eur Heart J. (2019) 40:1294302. doi: 10.1093/eurheartj/ehy731

176. Chao T-F, Lip GYH, Lin Y-J, Chang S-L, Lo L-W, Hu Y-F, et al. Incident risk factors and major bleeding in patients with atrial fibrillation treated with oral anticoagulants: a comparison of baseline, follow-up and delta HAS-BLED scores with an approach focused on modifiable bleeding risk factors. Thromb Haemost. (2018) 118:768-77. doi: 10.1055/s-0038-16 36534

177. Yoon M, Yang P-S, Jang E, Yu HT, Kim T-H, Uhm J-S, et al. Dynamic changes of CHA2DS2-VASc score and the risk of Ischemic stroke in asian patients with atrial fibrillation: A Nationwide Cohort study. Thromb Haemost. (2018) 118:1296-304. doi: 10.1055/s-0038-1651482
178. Chao T-F, Lip GYH, Liu C-J, Lin Y-J, Chang S-L, Lo L-W, et al. Relationship of aging and incident comorbidities to stroke risk in patients with atrial fibrillation. J Am Coll Cardiol. (2018) 71:12232. doi: $10.1016 /$ j.jacc.2017.10.085

Conflict of Interest: DG: Speaker for Bayer, BMS/Pfizer, Boehringer Ingelheim, Daiichi-Sankyo, Medtronic, Biosense Webster, and Boston Scientific. Proctor for Abbott. Research Grants from Medtronic, Biosense Webster, and Boston Scientific. GL: Consultant for Bayer/Janssen, BMS/Pfizer, Medtronic, Boehringer Ingelheim, Novartis, Verseon, and Daiichi-Sankyo. Speaker for Bayer, BMS/Pfizer, Medtronic, Boehringer Ingelheim, and Daiichi-Sankyo. No fees are directly received personally. DL has received investigator-initiated educational grants from Bristol-Myers Squibb and Boehringer Ingelheim; has been a speaker for Boehringer Ingelheim, Bayer, and Bristol-Myers Squibb/Pfizer; and has consulted for Bristol-Myers Squibb, Bayer, Boehringer Ingelheim, and Daiichi-Sankyo.

The authors declare that the research was conducted in the absence of any commercial or financial relationships that could be construed as a potential conflict of interest.

Copyright $\odot 2020$ Ding, Harrison, Gupta, Lip and Lane. This is an open-access article distributed under the terms of the Creative Commons Attribution License (CC $B Y)$. The use, distribution or reproduction in other forums is permitted, provided the original author(s) and the copyright owner(s) are credited and that the original publication in this journal is cited, in accordance with accepted academic practice. No use, distribution or reproduction is permitted which does not comply with these terms. 